\title{
Textures and Rare Earth Elements Composition of Banded Iron Formations (BIF) at Njweng Prospect, Mbalam Iron Ore District, Southern Cameroon
}

\author{
Dieudonne Charles Isidore Ilouga ${ }^{1,2^{*}}$, Cheo Emmanuel Suh ${ }^{3}$, Ghogomu Richard Tanwi ${ }^{1}$ \\ ${ }^{1}$ Department of Earth Sciences, Faculty of Science, University of Yaoundé I, Yaoundé, Cameroon \\ ${ }^{2}$ Camlron S. A., Yaoundé, Cameroon \\ ${ }^{3}$ Economic Geology Unit, Department of Geology and Environmental Science, University of Buea, Buea, Cameroon \\ Email: ${ }^{*}$ ilougacharles@yahoo.fr
}

Received September 25, 2012; revised October 22, 2012; accepted November 23, 2012

\begin{abstract}
The REE signature of banded iron formations (BIF) and martite-goethite mineralization of the Njweng ridge (South Cameroon) are used here to decipher the nature of the ocean during the period of BIF precipitation. The textures of typical BIF categories are also presented as the only sedimentary feature. Two types of BIF facies are present at Njweng: the oxide and silicate facies. These facies show two stages of phase transformations. The first is the transformation of the original magnetite mineral into martite by oxidation resulting in trellis texture; the second is a simultaneous transformation by hydration into goethite and dehydration into martite. The samples typically show LREE depleted patterns relative to HREE, a characteristic similar to that of modern seawater. Also the strong positive Eu anomalies from the samples indicate the involvement of hydrothermal plumes of volcanic origin such as at mid ocean ridges (MOR). Yttrium (Y) has a strong positive anomaly pointing to the transportation of REEs as aqueous complexes within these ancient seas. The BIF samples have no positive Ce anomalies, suggesting that the oceans at that time were more reducing with no Ce fractionation than in present day oceans. The martite-goethite mineralization rather shows a positive $\mathrm{Ce}$ anomaly that derived from the enrichment in REE during the weathering of REE-bearing minerals. These results are integrated into existing literature on REE in BIFs worldwide and provide new insights into these heretofore unstudied BIFs of the northern edge of the Congo Craton.
\end{abstract}

Keywords: REE; BIF; Martite; Magnetite; Alteration; Njweng; Cameroon

\section{Introduction}

The chemical coherence of rare earth elements (REE) and their similar ionic properties consequently give them similar geochemical behaviours. The element Yttrium (Y) is also often included in this category of elements because of its properties that are similar to those of some elements of this group. Rare earth elements have been widely used as geochemical tracers of various types of processes in the Earth Sciences e.g. environmental and hydrological studies [1-3], ancient and modern analogues for seawater composition [4-11], origin and deposition of iron formations, other iron oxide-rich sedimentary rocks [12-16]. The geological rock record extends back some 3.8 Ga into Earth history and samples of ancient seawater are not similarly preserved [17]. Chemical sediments (e.g., limestones, iron formations, phosphorites) precipitated from seawater have been identified to record

"Corresponding author. some of the trace elements and isotopic characteristics of the water mass from which they were formed [18]. With the absence of preserved samples of old seawater, the REE patterns of the sediments are used as proxies to infer some of the important chemical features of the ancient oceans. Iron formations being part of this have long been inferred as to have trapped the REE signature of seawater at the site of Fe precipitation as supported by experimented studies and results from natural systems $[18,19]$. More specifically $\mathrm{Eu}$ anomalies are tracers of hydrothermal input and Ce anomalies are used as redox proxies. Many aspects of the sedimentary origin of iron formations remain enigmatic because modern analogues are unknown. The intriguing question is still to know how these deposits were upgraded to iron ore [20,21], and whether REE signatures of enriched ores remained fix.

In this study we discuss the various banded iron formations (BIF) textural features, nature of iron-bearing oxides and their link with the deposition of iron forma- 
tions. Most importantly we use REE compositions of BIF and enriched martite-goethite mineralization from Njweng to compare the similarity of the REE trends and investigate the conditions of the system during the precipitation of BIF at Njweng in the northern part of Congo Craton. We also compare them with modern day seawater REE [22] and chemical sediments that best represent the REE signature of seawater at time of precipitation like limestone $[23,24]$.

\section{Geological Context of the Study Area}

The Njweng prospect is situated in the dense humid equatorial forest in the East-South-East of Cameroon. It is covered by equatorial climate with 4 seasons (two dry seasons and two wet seasons), and the topography belongs to that of the central-south plateau of Cameroon with an average elevation of $700 \mathrm{~m}$. The drainage pattern around the ridge is dendritic and oriented from south to the north, and separated by the ridge in two river systems (Karagoua and Bango) that take their sources at Mbarga to drain the area (Figure 1).

The Njweng iron prospect is located within the Ntem complex at the northern extension of the Congo Craton
(Figure 2). The Ntem complex is Archaean in age and its main lithologic units comprise schist, amphibolite, quartzite, Tonalite-Trondhjemite-Granodiorite (TTG) granitoids, orthopyroxene-garnet (charnockitic) gneiss, greenstone rocks and itabirite-like rocks $[25,26]$. The main structures in the Ntem complex are an E-W-trending (S1) foliation and numerous granitic plutons that are usually emplaced along a SW-NE-trending (S2) foliation. The S1 foliation dips steeply to the north and is locally deformed into mesoscopic isoclinal D2 folds [27]. The S2 foliation is a regional, steeply dipping planar fabric with variably oriented stretching lineation and large-scale open folds that are associated with N-S-trending sinistral and dextral strike-slip faults and mylonitic (S3) foliation [28]. This $\mathrm{S} 2$ foliation development is linked to dome-and-basin tectonics related to diapiric movements [29]. The oldest rocks of the Ntem complex belong to the granite-gneiss assemblage, $>3000 \mathrm{Ma}$ [30], followed by granulite-facies metamorphism, granitoid plutonism and charnockitisation at 2900 - 2500 Ma. A major Eburnean tectono-metamorphic event at $\sim 2000$ Ma resulted in amphibolite-facies metamorphism. During the Pan-African $(\sim 600 \mathrm{Ma})$, a mobile belt, the Yaoundé series, drifted southward and

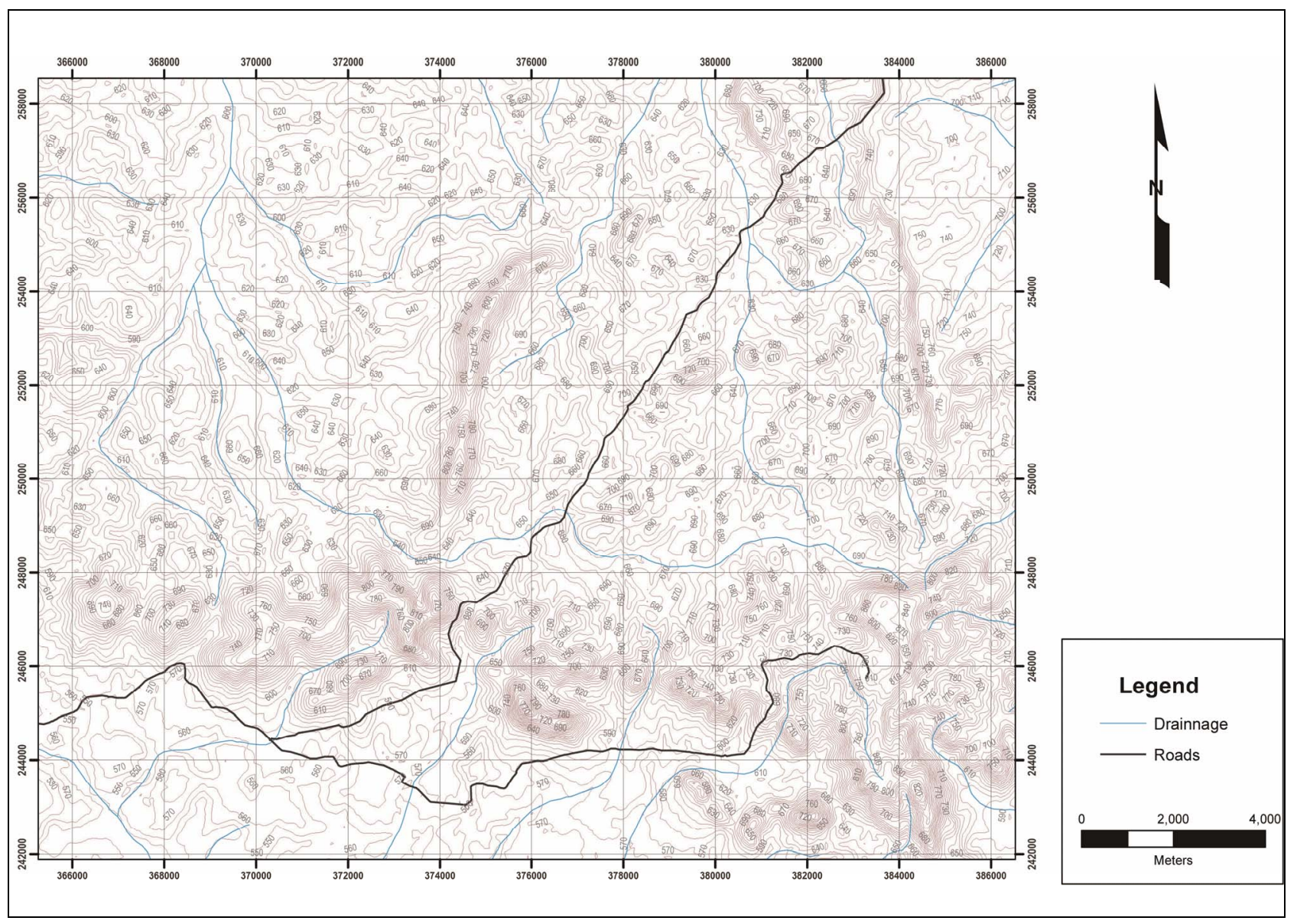

Figure 1. Orographic map of the study area with the Mbarga deposit. 


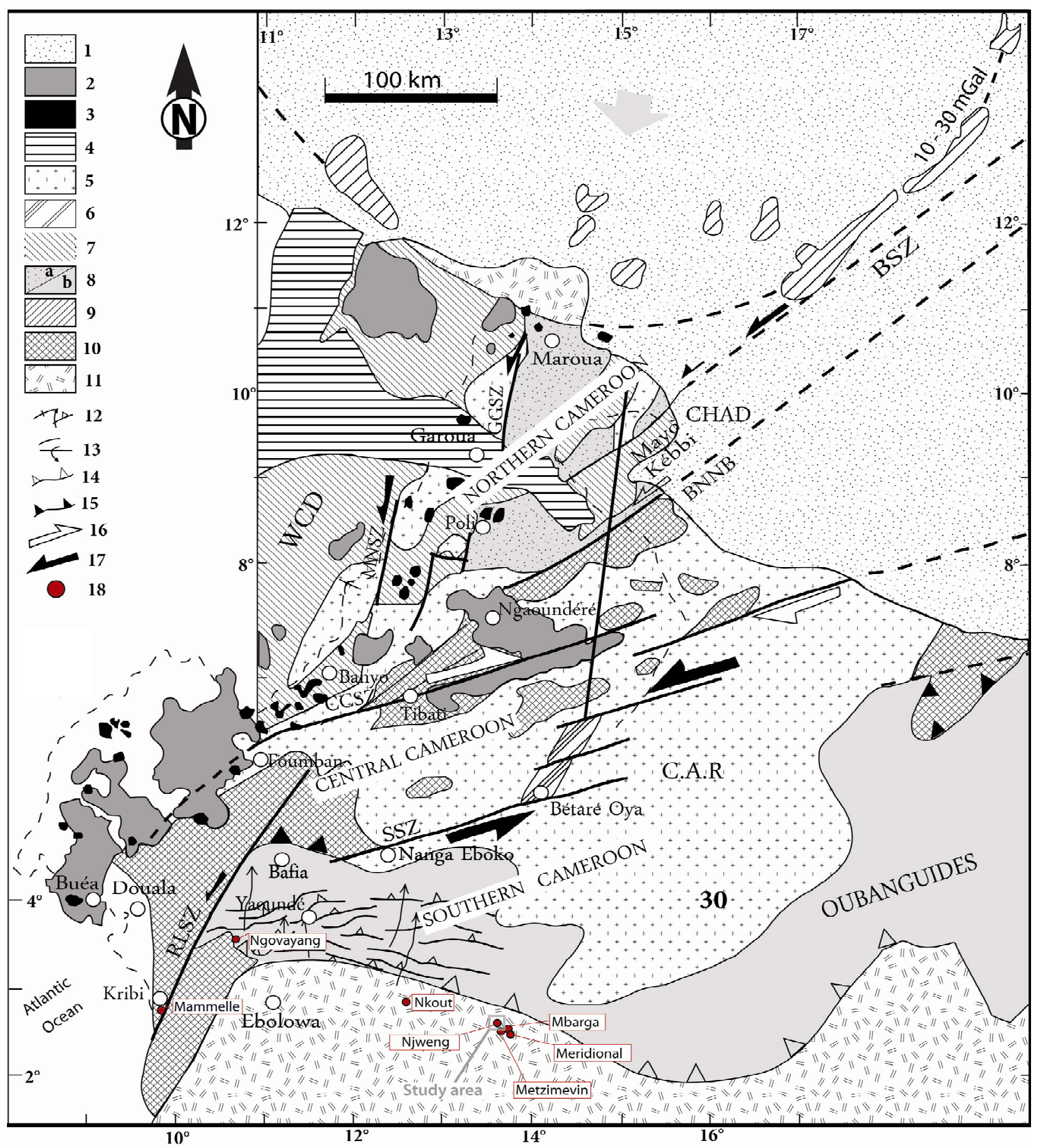

Figure 2. Pan-African structural map of Cameroon and location of the study area (modified from [25]). 1: Quaternary sediments; 2: Cameroon Line volcanism; 3: Cameroon Line plutonism; 4: Mesozoic sediments (Benue Trough); 5: Late syntectonic subalkaline granitoids; 6: Lom syntectonic basin (meta-sediments, conglomerates, volcanic ashes and lavas); 7: Western Cameroon Domain (WCD; early syntectonic basic to intermediate calc-alkaline intrusions, 660 - 600 Ma); 8 a: Poli Group (active margin Neoproterozoic supracrustal and juvenile intrusions), 8b: Yaoundé Group (intracratonic deposits); 9: Massenya-Ounianga gravity highs (10 - 30 mgal); 10: Adamawa-Yadé and Nyong Paleoproterozoic remnants; 11: Craton and inferred craton; 12: $S_{2}$ foliation and $L_{2}$ lineation trends; 13: $F_{2}$ upright and overturned antiforms; 14 : Syn- $D_{2}$ main frontal thrust zone; 15: Syn- $D_{1}$ thrust zone (separates the LP to MP zone in the North from the HP zone in the South); 16: Syn- $D_{3}$ sense of shear movement; 17: Syn- $D_{2}$ sense of shear movement. Large grey arrow represents syn- $D_{1-3}$ regional main stress direction. Thick lines = shear zones (SZ): BSZ = Balché SZ; BNMB = Buffle Noir - Mayo Baléo SZ; CCSZ = Central Cameroon SZ; GGSZ = Godé-Gormaya SZ; MNSZ = Mayo Nolti SZ; RLSZ = Rocher du Loup SZ; SSZ = Sanaga SZ; 18: Main Iron occurrences in Cameroon. 
collided with the Ntem complex [25]. The Yaoundé series was consequently thrust over the Ntem complex, reactivating under brittle-ductile conditions, NE-SW-trending shear zones in the Ntem complex. The Pan-African overprint also expressed itself in the form of late granitic plutonism. Itabirite rocks in the Ntem complex are considered to be Archaean in age [31].

The Njweng prospect outcrops as a ridge with a N-S orientation (Figure 3) and is part of a wider iron ore district locally termed "the Mbalam Iron Ore District", that is currently being evaluated by the Cameroon Iron Ore company (CamIron) [32], and which comprises the Mbarga deposits, Metzimevin, Mbarga South and Meridional prospects (Figure 2). The main rock types of the Njweng prospect are metamorphosed chemical sediments (BIFs with varying degrees of magnetite, hematite, and goethite enrichment), metagranitoids and amphibolites. In terms of structure, this prospect depicts a folded structure. The dominant structure in the area is the early $\mathrm{N}$-verging recumbent F1 fold which was overprinted by a late $\mathrm{W}$-verging open F2 fold. Both F1 and F2 fold axes are discernable in (Figure 3). Outcrop observations also reveal this folding in itabirite, and the itabirite banding strikes $\mathrm{N}-\mathrm{S}$ with a near vertical dips (average $75^{\circ}$ ), and a dip direction E or W (Figures 4(a) and (b)).

\section{Methods of Study}

Selected representative samples of iron ore-bearing facies were chosen for petrographic studies, ore microscopy, and geochemical analyses following a careful field mapping of the prospect. Polished thin sections were prepared at the Mineral Resources Institute (MRI) of the Technical University of Clausthal in Germany and studied under ore microscope (reflected light in air and oil immersion) both at Clausthal and at University of Buea.

Whole rock geochemical composition of representative samples was obtained at ACME Laboratory in Canada using the inductively coupled plasma mass spectrometry (ICP-MS) method following a lithium metaborate/ tetraborate fusion and nitric acid digestion of a $0.2 \mathrm{~g}$ sample. Various standards were used and data quality assurance was by running these standards between samples as unknowns.

\section{Results}

\subsection{Textures and Ore Mineralogy}

The Njweng protore is essentially an unenriched Banded Iron Formation (BIF) (Figures 4(a) and (b)). It is associated with spots of enriched martite-goethite mineralization. Most samples show good Fe oxide-quartz banding and some display microfolding (centimetric-scale) of mesobands ranging in thickness from $\sim 1 \mathrm{~mm}$ and rarely reaching $1 \mathrm{~cm}$ (Figure 4(a)). The iron formation covers a wide palette of textural and mineralogical facies of BIF. Two facies types of BIF are observed at Njweng based on their mineralogy, namely the oxide and silicate facies.

\subsubsection{Oxide Facies BIF}

The oxide facies BIF is composed of quartz as the main gangue mineral associated with various iron oxides, principally martite, goethite and magnetite (Figures 4(a) and 5(a)). Minor phases present include monazite, apatite, rare pyrite and pyrrhotite. This BIF facies has an almost homogeneous mineral composition, with little textural variations that permit their differentiation into various subtypes, including granular and massive, specularite (slaty), granular, massive and weakly banded BIF (Figure 5). The granular and massive type is composed of quartz bands and two ferruginous layers: one with magnetite grains in a brown massive martite matrix, and a second gray to brown massive bands. Both layers display very little quartz. The massive bands are composed of rhythmical gray massive bands and white to yellowish stained silica bands; the granular bands show white silica layers and brown granular ferruginous bands, while the specularite bands type display some white silica and grey shiny slender grains of specular hematite rich bands. A poor alignment of xenomorphic martite, goethite and relict magnetite grains is discernable in the weakly banded sub-type BIF. In this facies, iron oxides are disseminated in a largely siliceous matrix that makes up over $60 \%$ of the rock. Weathering in both the oxides and silica layers on this facies is similar.

\subsubsection{Iron Oxide Layers}

Two main types of iron oxide layers were discriminated within the BIF: the massive and the granular type bands. The massive iron oxide bands show a dense network of martite crystals interconnected by goethite with some magnetite relicts and rare quartz grains (Figure 5(b)). The granular iron oxide bands show aggregates of coarse hexagonal and elongated crystals of martite with voids and pseudomorphic relicts of magnetite in the nuclei of large grains (Figure 5(c)). In general the bands are locally broken and disrupted (Figure 5(d)). Pores and intergranular spaces are often filled by recrystallised quartz and goethite. The martite appears as xenomorphic to subeuhedral grains with the trellis texture of the original magnetite, and magnetite relicts at the centre of crystals (Figures 5(c) and 6(a)). Euhedral to sub-euhedral hexagonal martite crystals pseudomorphed after magnetite are frequent in polished thin sections. A zoning transformation also occurs with magnetite being transformed into goethite by hydration, and subsequently into martite by dehydration (Figure 5(c)). Martite and specular hematite can be found fused together forming a dense network or occur as disseminated needle-like crystals (Figure 6(b)). 


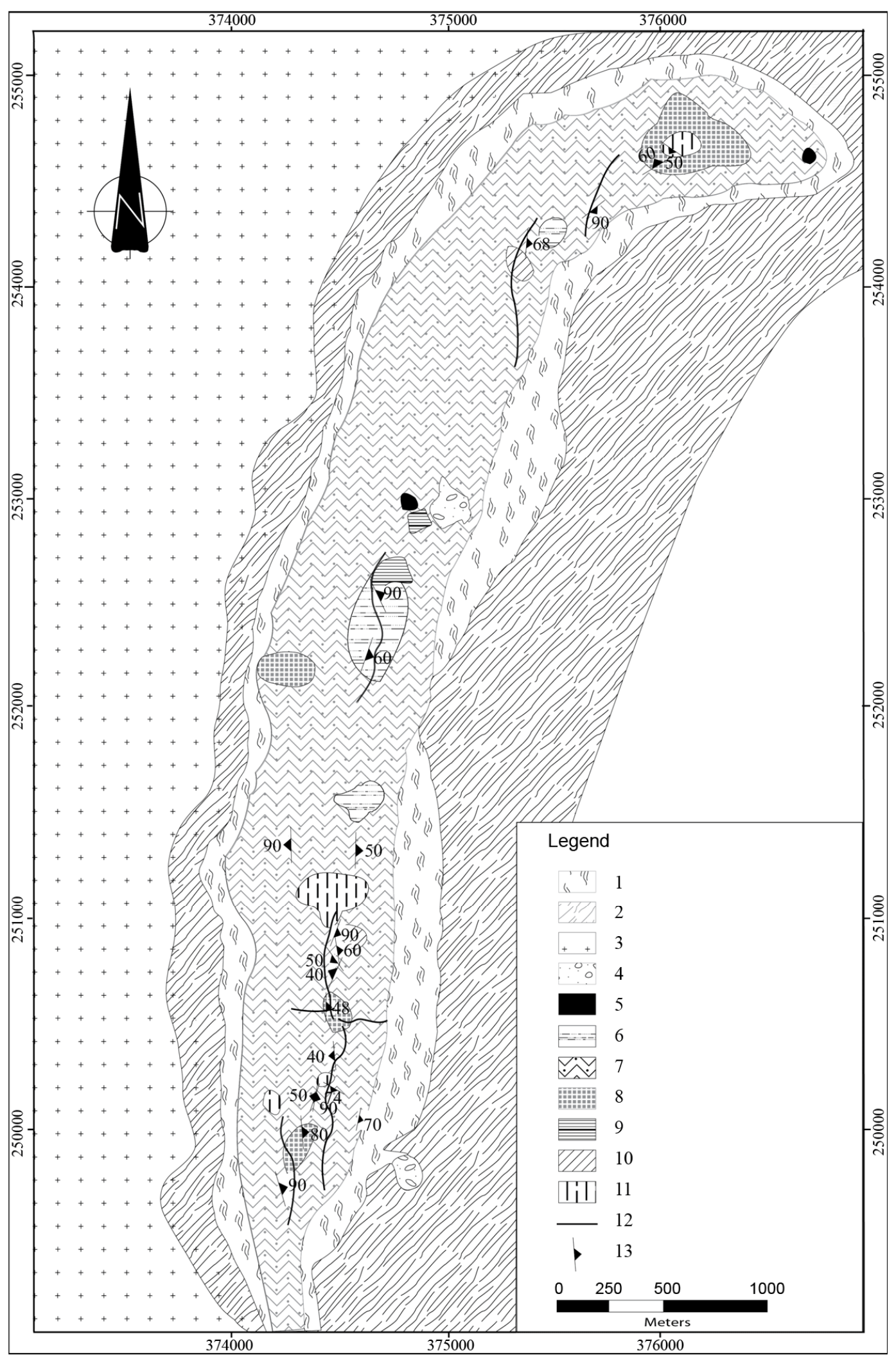

Figure 3. Geological sketch of Njweng mapped for the first time using combined aeromagnetic data and ground-truthing. 1: amphibolite; 2: Garnet amphibolite; 3: Granodiorite; 4: Breaccia/Conglomerate BIF; 5: Martite-Goethite; 6: Granular and Massive bands BIF; 7: Granular bands BIF; 8: Massive bands BIF; 9: Weakly banded BIF; 10: Specularite bands BIF; 11: Amphibolitic Bands BIF (silicate facies); 12: Fault; 13: Strike and Dip of bed. 


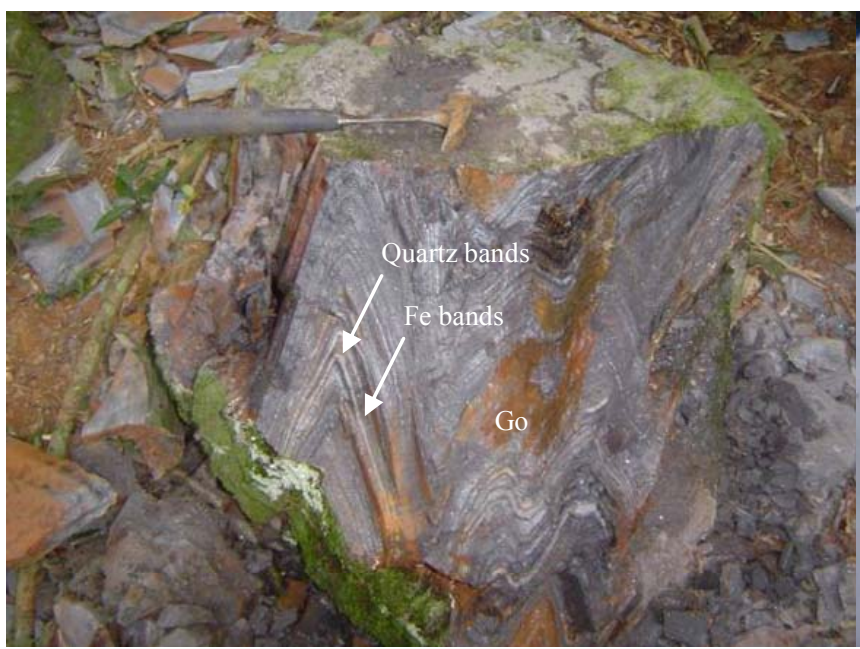

(a)

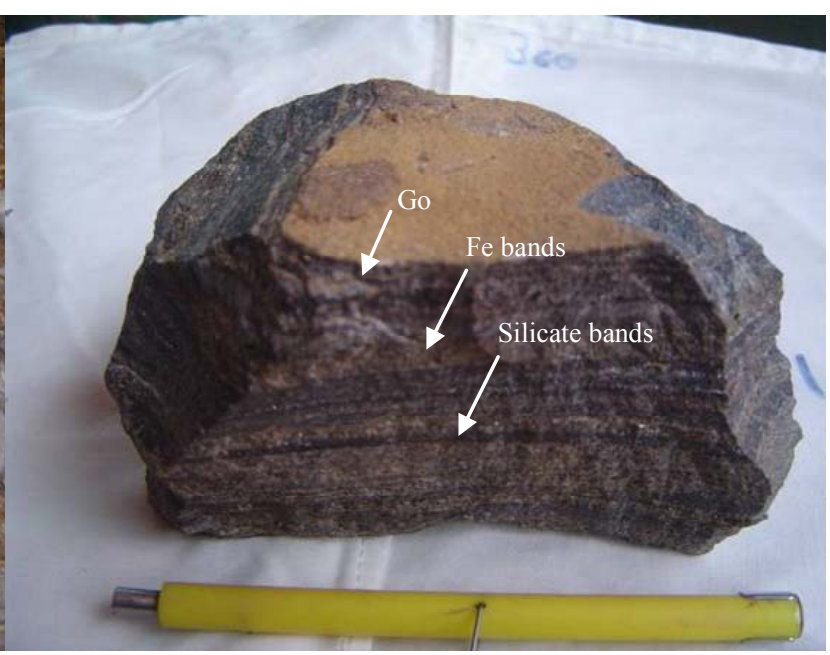

(b)

Figure 4. (a) Intensely folded oxide facies BIF with alternative silica and iron banding, stained by goethite (Go). (b) Banded silicate facies BIF sample with some goethite coating.

Magnetite preferentially forms thin horizontal bands towards the centre of the iron-rich layers, and also appears as relicts at the centre of some martite crystals in the boundary of the band (Figure 6(c)). These skeletal relicts of the original magnetite grains and the xenomorphic shape of martite are widespread in thin sections (Figure 5) and show the advanced state of weathering in the iron bands. Goethite appears either as small isolated sub-euhedral crystals or xenomorphic blasted shapes. Overgrowths of goethite over paragenetically older martite and hematite are widespread at the boundary of some martite crystals (Figure 6(d)). They fill intergranular spaces between the martite grains, or in the porous areas at the centre of martite. This texture is locally associated to coarse bladed specular hematite.

\subsubsection{Siliceous Layers}

The siliceous layers are essentially composed of quartz with disseminated euhedral or xenomorphic blasted shape martite grains and elongated small needle-like crystals of specularite hematite in a very rich quartz matrix. The martite crystals are porous marking quartz dissolution. Quartz grains are equigranular and granoblastic-polygonal with intergranular triple junctions that suggest static recrystallization (Figure 6(b)). Bladed quartz grains are closely associated to magnetite crystals. The intergranular space is filled by goethite and martite, with xenomorphic shapes. The martite observed here is similar to that present in iron rich bands, with apatite and monazite grains linked to quartz and magnetite, respectively.

\subsubsection{Silicate Facies BIF}

The silicate facies (amphibolitic facies) at outcrop level is commonly characterized by abundant brown goethite pseudomorphs after silicate minerals (amphiboles) (Fig- ure 4(b)). The bands present similar textures as above, in addition to the alternating white to yellowish silica bands and light green to dark massive iron oxides bands. The common minerals that accompany the silicate in reflected light microscopy are martite, magnetite, goethite, and quartz (Figure 5(f)). In general, the weathering process that affected iron oxides in the various BIF facies is similar. They show variably hematitized magnetite (martitization), plus goethite weathering. The hematitization of magnetite may be incipient or nearly complete with only very tiny relicts of magnetite (Figures 5(c), 6(a) and (c)). The weathering affects preferentially the magnetite component. The BIF type shows alternating silica and laminae of martite/hematite layers, respectively ranging from $0.41 \mathrm{~mm}$ to $1 \mathrm{~mm}$ and from $0.51 \mathrm{~mm}$ to $0.88 \mathrm{~mm}$ for microbands with both sharp and gradational contacts. These layering are sometimes sandwiched by a thin goethite veneer (Figure 5(a)). Some iron oxide bands are porous, probably due to leaching of silica inclusions. A thin limonitic coating interstitial to the goethite grains is observed. No polished section of the enriched martitegoethite mineralization was done.

\subsection{Iron Ore Microscopy}

Detailed microscopic observation of the oxide facies BIF layers showed granoblastic and porphyroblastic magnetite crystals with poikilitic texture and numerous quartz inclusions (Figure 7(a)). In addition to this, inclusions of apatite and monazite (Figures 7(b) and (c)) are found in magnetite and quartz, respectively. These represent the main phases bearing REEs. The energy dispersive pattern in the identified monazite shows that it is REE-rich (Figure 8(a) and Table 1).

The silicate facies showed a Mg-Fe silicate that pre- 


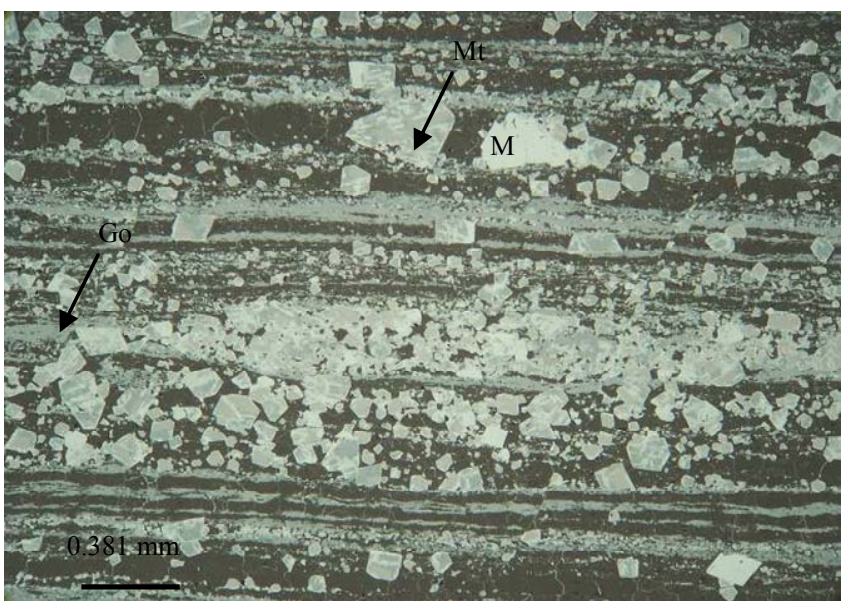

(a)

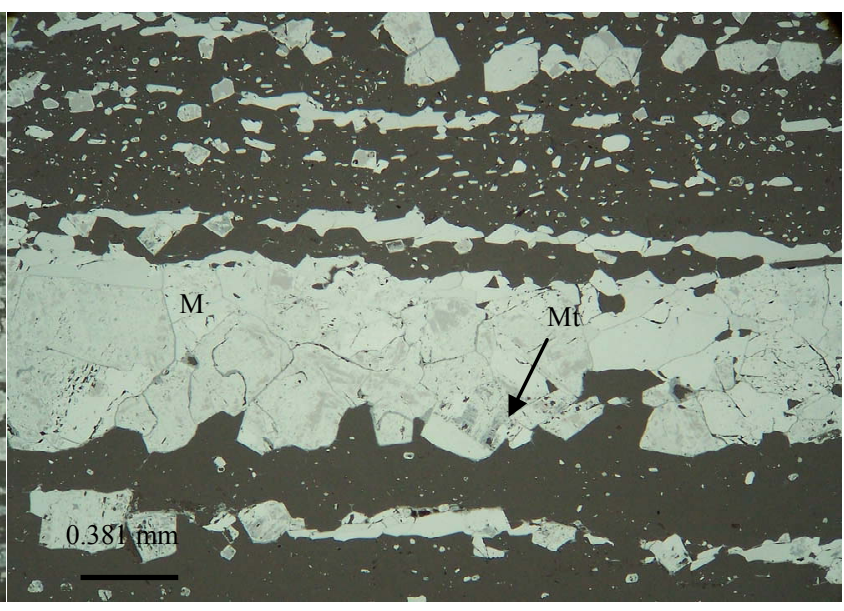

(b)

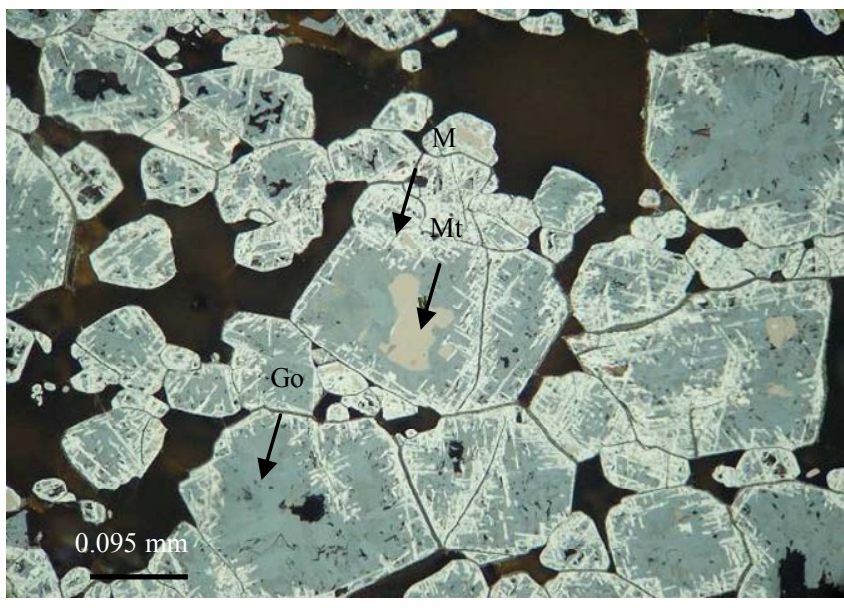

(c)

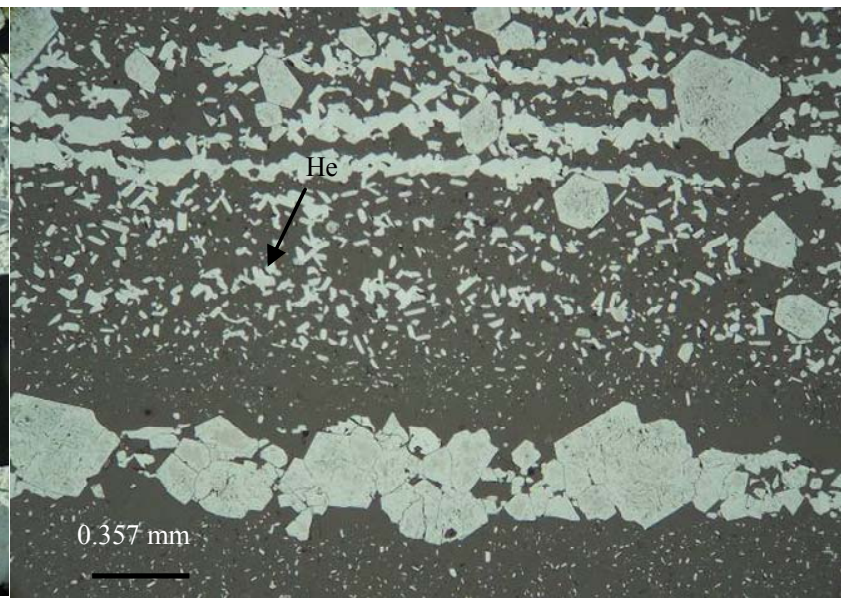

(d)

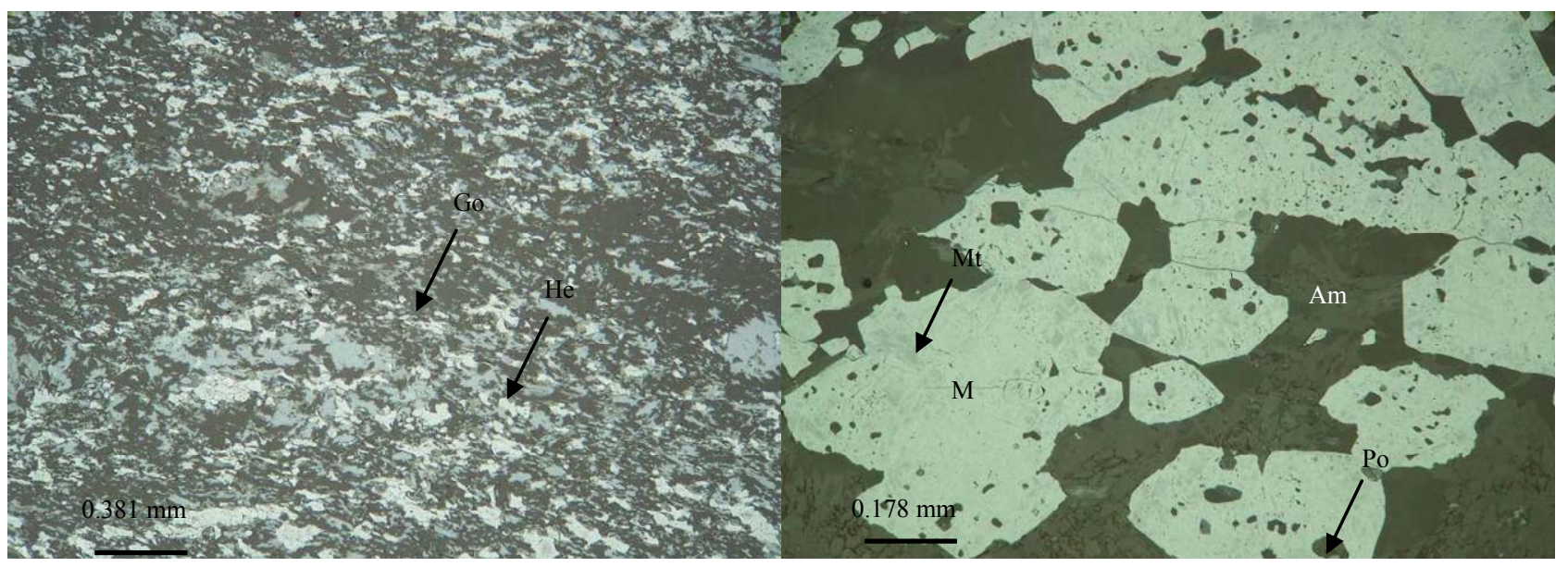

(e)

(f)

Figure 5. Air (a)-(f) and oil (c) immersion reflected-light photomicrographs of iron oxides of Njweng Itabirite. (a) Granular and massive band BIF with coarse martite $(\mathrm{M})$ crystals in rhythmic banding with magnetite (Mt) relicts at centre of martite grains and layering sandwich by a thin goethite veneer; (b) Massive bands, martite rich with some pore and magnetite relicts in grains; (c) Granular bands aggregates of coarse hexagonal crystals of martite showing alteration of magnetite into goethite (Go) then secondary transformation into martite; (d) Specularite bands texture with silica band (opaque) associated with locally broken and disrupted iron oxides bands with disseminated needle-like specularite hematite crystals; (e) Disseminated xenomorphic martite and goethite grains with some pores; (f) Amphibolitic bands Trellis texture and abundant pores (Po) in sub-euhedral and xenomorphic martite crystal. Some mesh-like amphibole Am) between martite grains. 


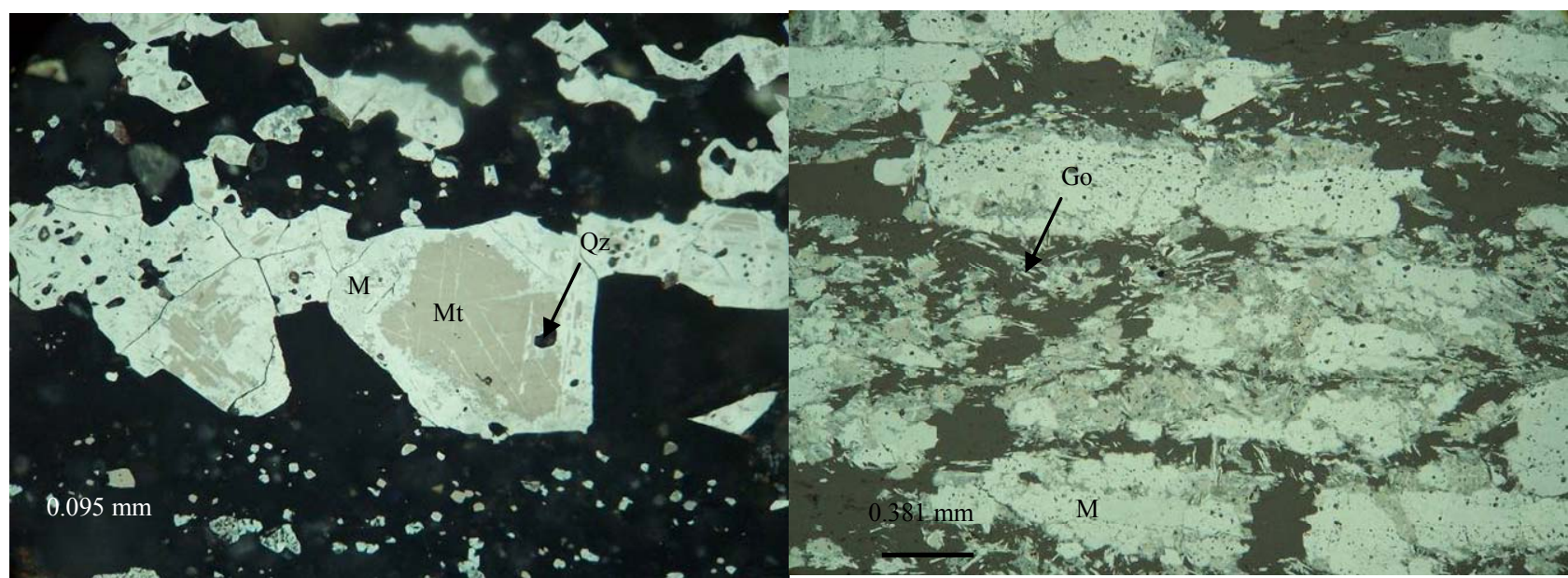

(a)

(b)

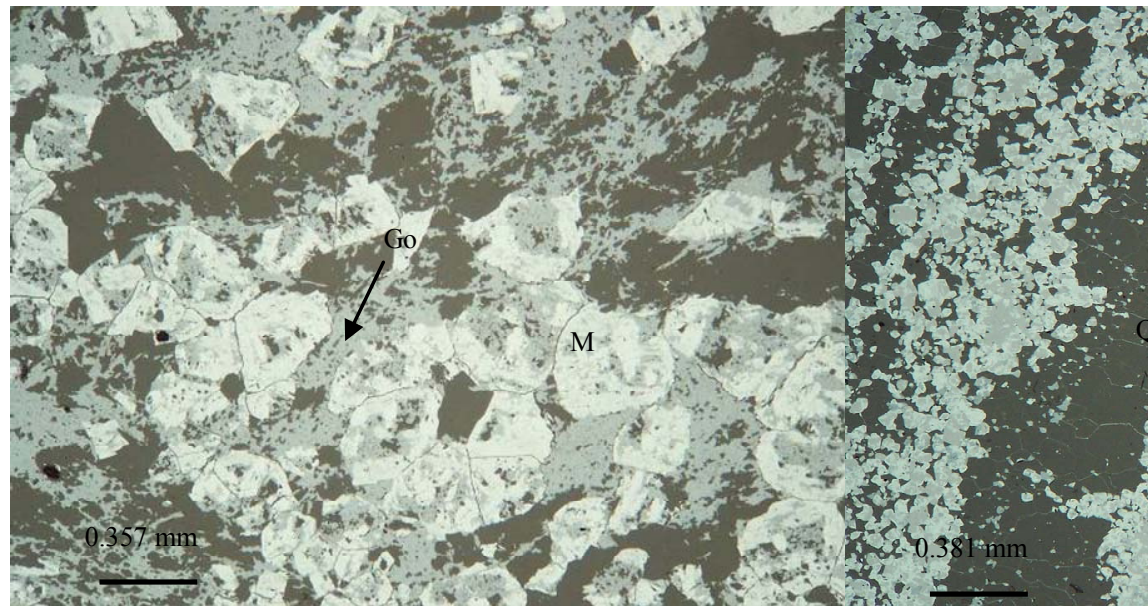

(c)

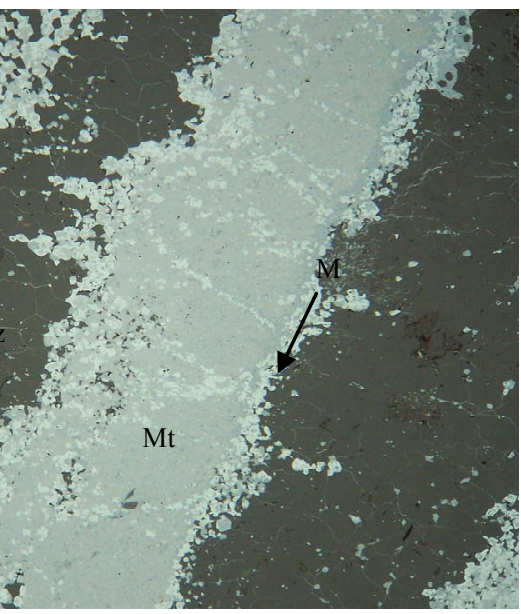

(d)

Figure 6. Oil (a) and air (b)-(d) immersion reflected-light photomicrographs of Njweng Itabirite. (a) Relicts of magnetite at centre of martite crystals with trellis texture, quartz $(\mathrm{Qz})$ inclusions, and intergranular space filled by goethite; (b) Mesh of needle-like coarse bladed specularite surrounding the martite crystal; (c) Overgrowth blasted shape goethite (Go) over paragenetically older martite (M); (d) Magnetite (Mt) bands preferentially forms towards the centre of the iron-rich layers.

sents evidence of their transformation into phosphates and Fe-bearing silicate, respectively (Figures $\mathbf{7 ( d )}$ and (e)). The silicate minerals have magnetite of inclusions (Figure 7(e)) indicating that the original mineral was coeval with magnetite precipitation. These silicates are Fe$\mathrm{Mg}$ amphibole of the grunerite-cummingstonite series (Table 2). The energy dispersive pattern showed that, the silicate phase is $\mathrm{Si}, \mathrm{Mg}$ and $\mathrm{Fe}$ dominant (Figure 8(a) and Table 3). Detailed microprobe data of the silicate phase and monazite are found in Table 2. The silicates might be alteration products after evaporites initially present in the system.

The enriched martite-goethite mineralization, on its own, is very porous and composed of martite and goethite with some silica remnants and voids. The mineralization consists of relict thin bands of martite and goethite separated from rows of voids due to the leaching of silica (Figure 7(f)).

\subsection{Rare Earth Elements Geochemistry}

The REEY contents of oxide silicate facies BIF and that of the martite-goethite from Njweng in the Mbalam iron ore district are listed in Table $\mathbf{3}$ and presented in shalenormalized diagrams using the Post-Archaean Australian Shale (PAAS) [33] (Figure 9). These data show low $\sum \operatorname{REE}(6-24)$ but which clearly increases with the increase in abundance of $\mathrm{La}, \mathrm{Nd}$, and $\mathrm{Ce}$ in BIFs and in the martite-goethite samples.

\subsubsection{Oxide Facies BIF}

The REE patterns of oxide facies BIF are separated according to textural varieties as mentioned above. From Table 3, it appears that, $\mathrm{La}, \mathrm{Ce}$, and $\mathrm{Nd}$ are the most abundant elements in all samples of the oxide facies BIF types. The $\sum$ REE varies between 6.77 and $23.00 \mathrm{ppm}$ (average $11.92 \mathrm{ppm}$ ). However there is a tendency for the 


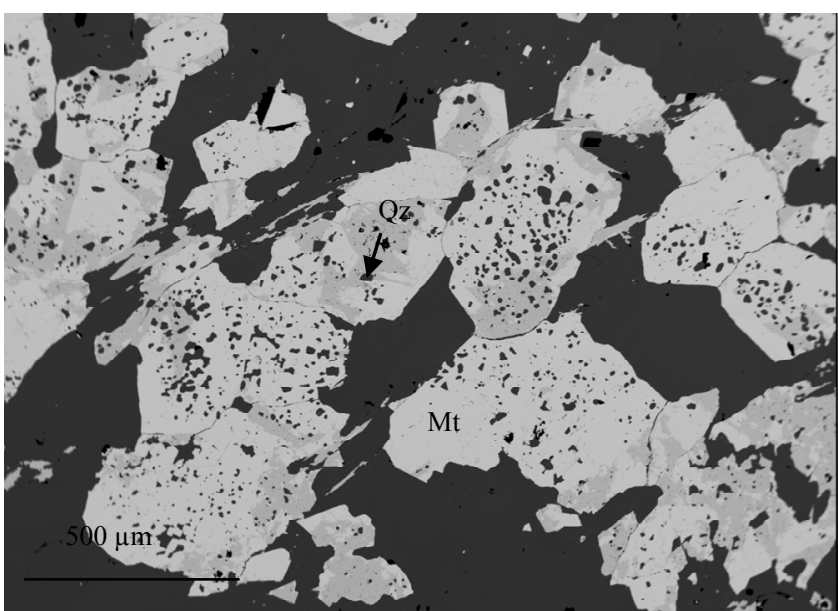

(a)

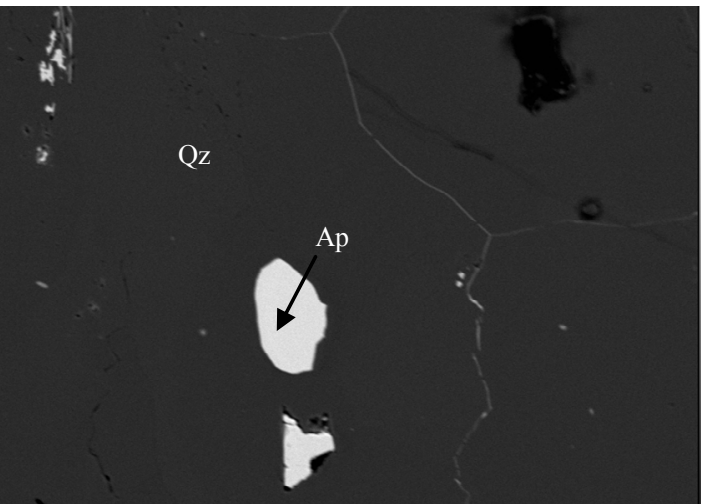

$100 \mu \mathrm{m}$

(b)

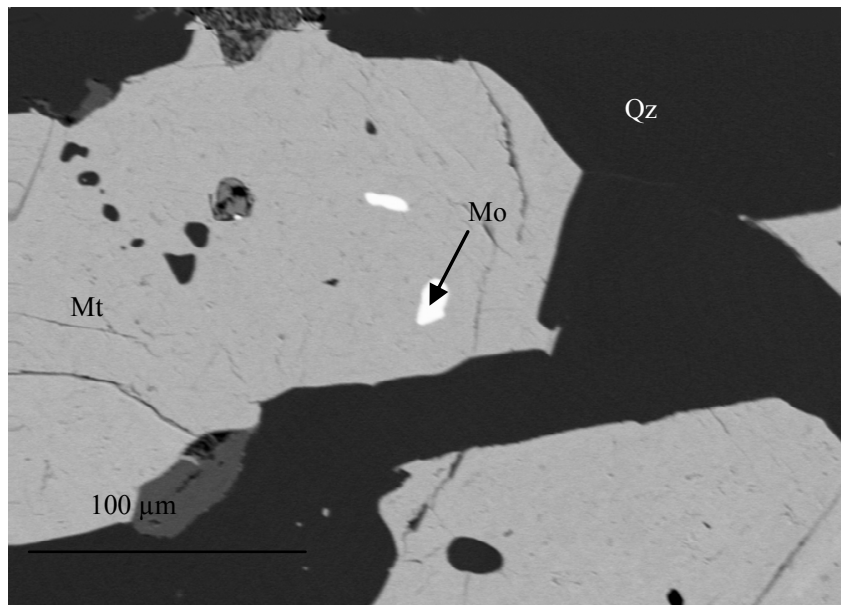

(c)

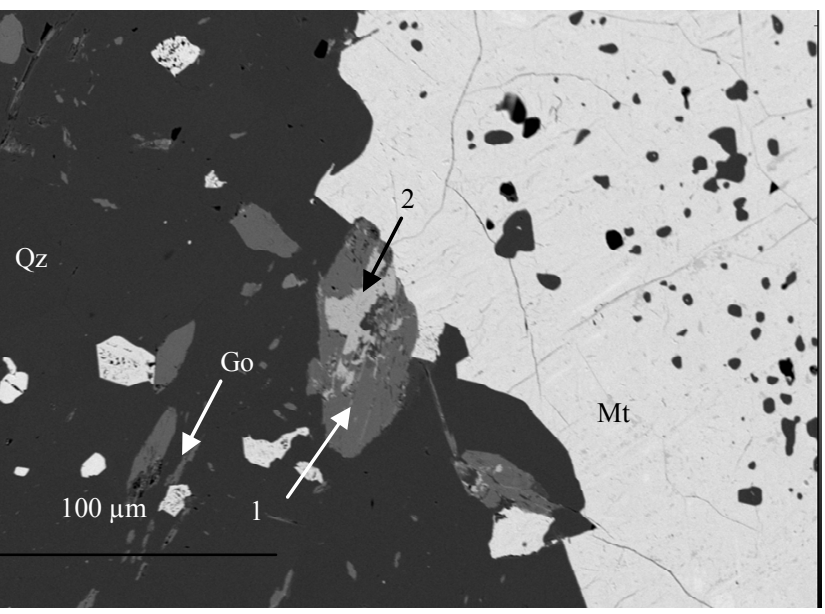

(d)

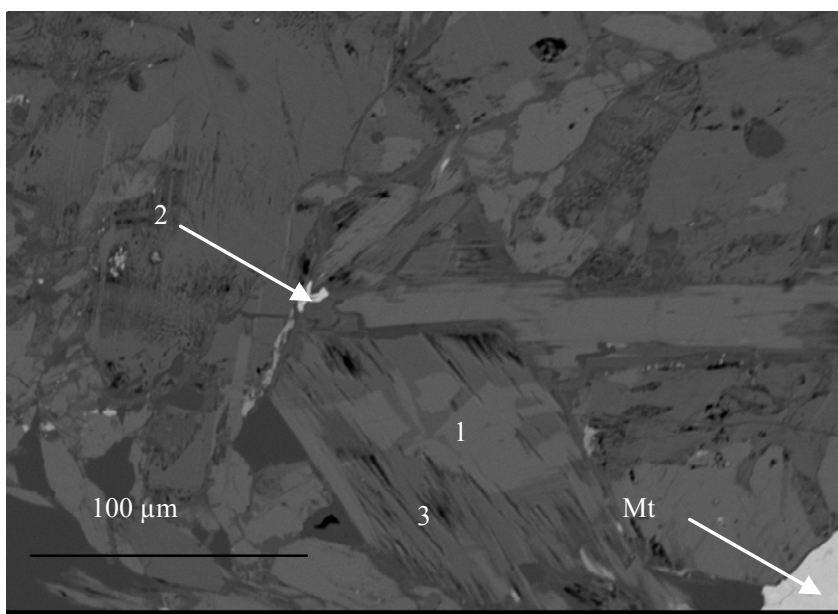

(e)

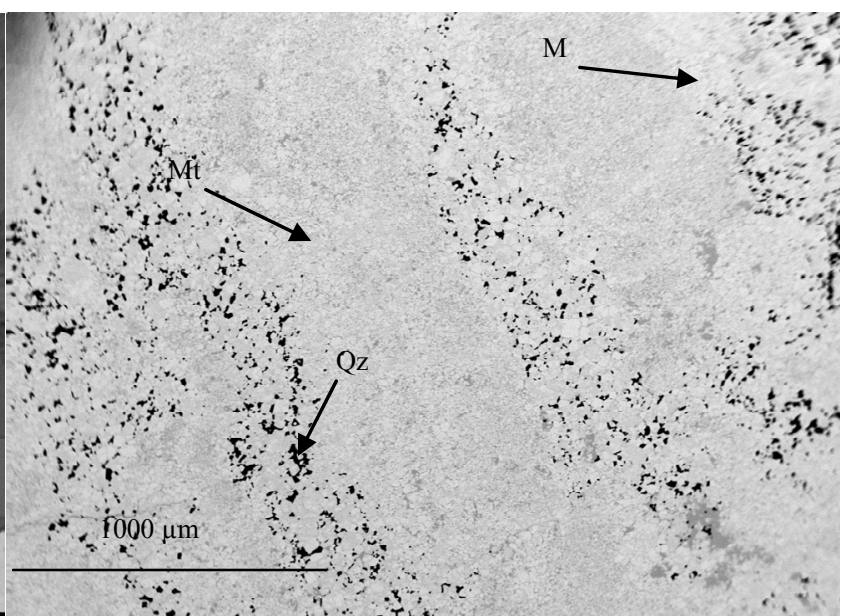

(f)

Figure 7. (a)-(f) Backscattered secondary electron image of BIF sample from Njweng. (a) Magnetite (Mt) grains with numerous quartz (Qz) inclusions; (b) Apatite (Ap) inclusion in silica band with statistical triple point of quartz grains; (c) Monazite (Mo) and quartz grains inclusions in magnetite; (d) Porphyroblastic magnetite grain (Mt) with recrystallized quartz (opaque) inclusions. Mg-Fe silicate phase (1) shows progressive alteration to an Fe-bearing phosphate (2) at its core. Bladed goethite (Go) in the quartz-rich matrix; (e) Cleavage controlled alteration of Mg-Fe silicate (1) to Fe-bearing silicate (3) and Fe-bearing phosphate (2). Silicate mineral showing magnetite (Mt) inclusion; (f) Relicts banding preserved in the martite-goethite with some voids and quartz. 


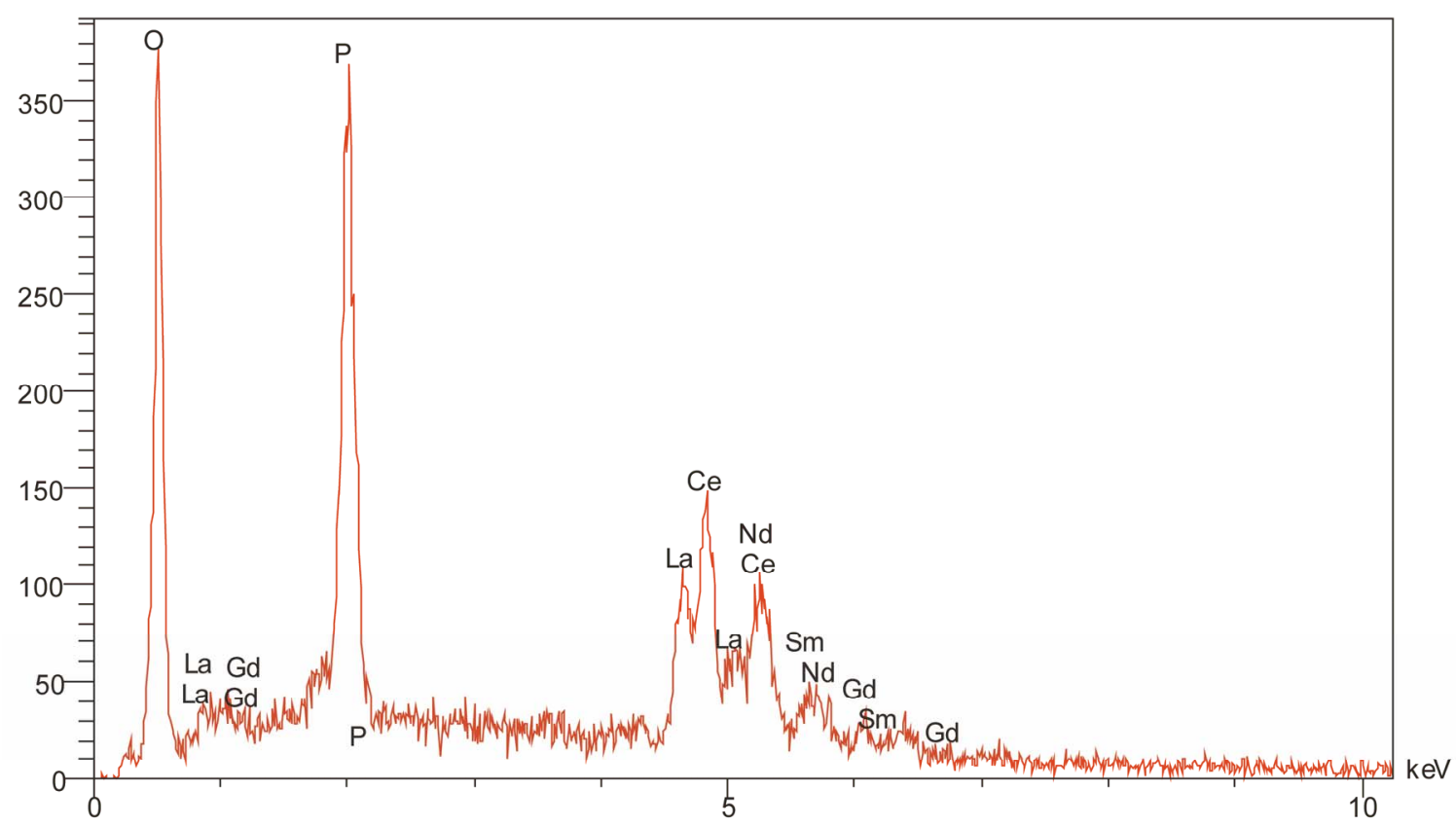

(a)

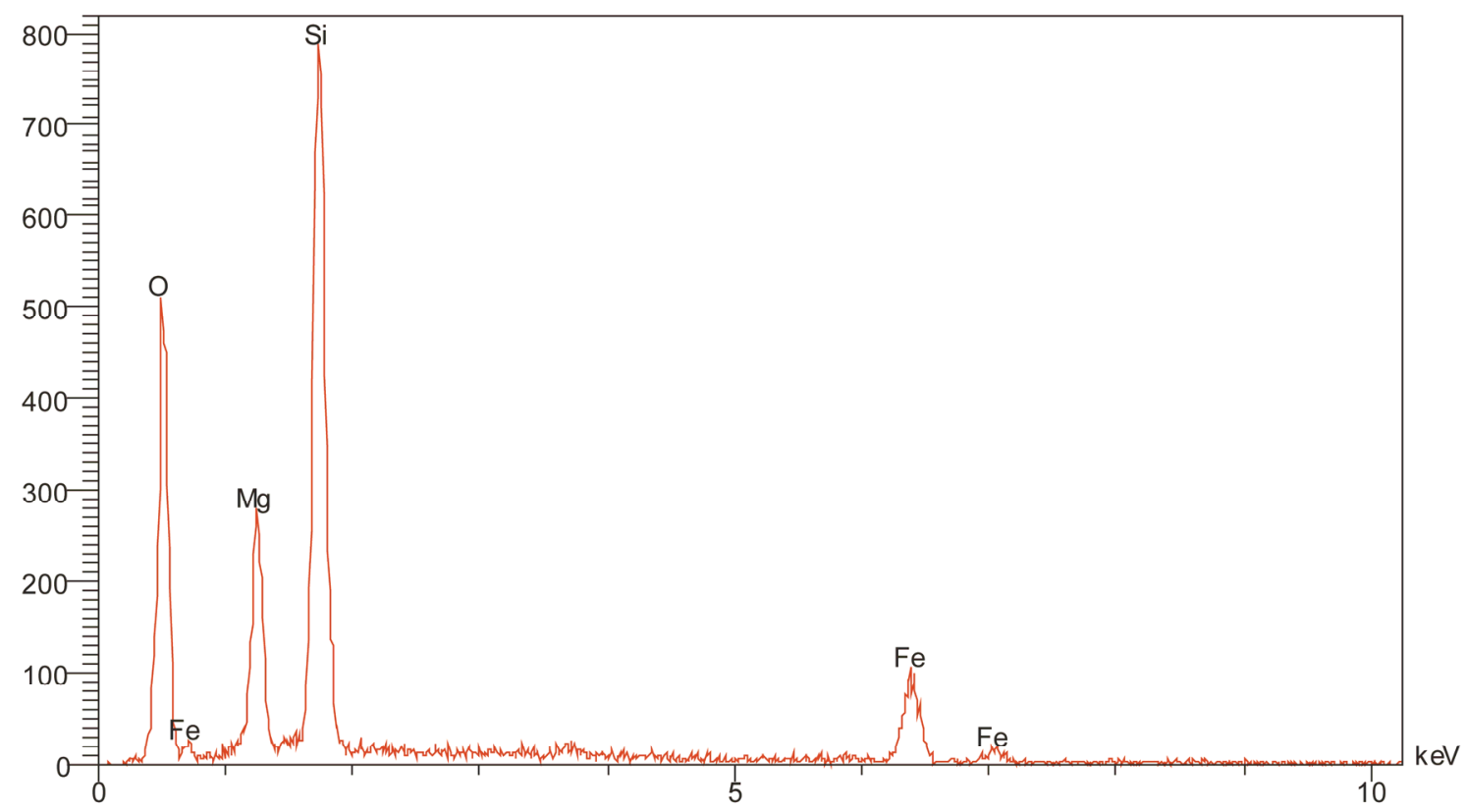

(b)

Figure 8. (a) Energy dispersive (EDS) pattern depicting the composition of the monazite as being Ce-La rich; (b) EDS of the silicate phase showing Si Mg and Fe dominant.

granular and the massive bands to be richer in $\sum$ REE as compared to the other textural varieties of the oxide facies BIF. All the samples exhibit a decrease in concentration from the LREE to HREE (average La/Yb $\mathrm{Y}_{\mathrm{PAAS}}=0.33$ ) and a depletion of middle REE relatively to heavy HREE (average $\mathrm{Dy} / \mathrm{Yb}_{\mathrm{PAAS}}$ ranges from 0.81 to 0.90 ). This depletion occurs in the light rare earth elements group (average $\mathrm{La} / \mathrm{Sm}_{\text {PAAS }}$ ranges from 0.47 to 0.84 ), as well as in the HREE group (average $\mathrm{Dy} / \mathrm{Yb}_{\mathrm{PAAS}}=0.85$ ). All the tex- tural varieties depict strong positive Eu anomalies ranging from 2.13 to 2.99 (average $\mathrm{Eu} / \mathrm{Eu}^{*}=2.62$ ), and moderate positive $\mathrm{Y}$ anomalies (average $\mathrm{Y} / \mathrm{Y}^{*}=1.42$ ). Ce anomaly is negative and ranges from 0.68 to 0.88 (average $\mathrm{Ce} / \mathrm{Ce}^{*}$ $=0.81)$. It is worth noting that, positive Eu and negative $\mathrm{Ce}$ anomalies are more pronounced in the granular and massive as well as in the weakly banded BIF of the oxide facies at Njweng as observed in Table 3, highlighting the complex behaviour of these two elements in the series. 
Table 1. Representative microprobe data of monazite from BIF sample of the Njweng define a simple arm.

\begin{tabular}{|c|c|c|c|c|c|c|c|c|c|c|c|c|}
\hline Samples & $\mathrm{CaO}$ & $\mathrm{P}_{2} \mathrm{O}_{5}$ & $\mathrm{SiO}_{2}$ & $\mathrm{La}_{2} \mathrm{O}_{3}$ & $\mathrm{Ce}_{2} \mathrm{O}_{3}$ & $\mathrm{ThO}_{2}$ & $\mathrm{U}_{2} \mathrm{O}_{3}$ & $\mathrm{Pr}_{2} \mathrm{O}_{3}$ & $\mathrm{Nd}_{2} \mathrm{O}_{3}$ & $\mathrm{SmO}$ & $\mathrm{PbO}$ & Total \\
\hline 1 & 0.25 & 18.40 & 0.02 & 16.99 & 26.10 & 0.03 & - & 2.49 & 9.25 & 17.4 & 0.06 & 91.00 \\
\hline 2 & 0.24 & 17.60 & 0.02 & 17.99 & 26.08 & 0.03 & - & 2.49 & 9.25 & 17.4 & 0.06 & 91.18 \\
\hline 3 & 0.25 & 18.20 & 0.02 & 16.89 & 26.08 & 0.03 & - & 2.49 & 9.25 & 17.4 & 0.06 & 90.70 \\
\hline 4 & 0.25 & 17.90 & 0.02 & 16.91 & 26.07 & 0.03 & - & 2.49 & 9.25 & 17.4 & 0.06 & 90.42 \\
\hline 5 & 0.26 & 18.10 & 0.02 & 17.10 & 26.04 & 0.03 & - & 2.49 & 9.25 & 17.4 & 0.06 & 90.77 \\
\hline 6 & 0.25 & 17.50 & 0.02 & 16.96 & 26.09 & 0.03 & - & 2.49 & 9.25 & 17.4 & 0.06 & 90.07 \\
\hline 7 & 0.27 & 18.20 & 0.02 & 16.25 & 26.09 & 0.03 & - & 2.49 & 9.25 & 17.4 & 0.06 & 90.08 \\
\hline 8 & 0.26 & 19.50 & 0.02 & 16.97 & 26.08 & 0.03 & - & 2.49 & 9.25 & 17.4 & 0.06 & 92.07 \\
\hline 9 & 0.23 & 17.90 & 0.02 & 16.88 & 26.11 & 0.03 & - & 2.49 & 9.25 & 17.4 & 0.06 & 90.40 \\
\hline 10 & 0.24 & 18.60 & 0.02 & 16.89 & 26.07 & 0.03 & - & 2.49 & 9.25 & 17.5 & 0.06 & 91.15 \\
\hline 11 & 0.27 & 18.00 & 0.02 & 16.90 & 26.08 & 0.03 & - & 2.49 & 9.25 & 17.4 & 0.06 & 90.51 \\
\hline 12 & 0.24 & 18.30 & 0.02 & 16.79 & 26.08 & 0.03 & - & 2.49 & 9.25 & 17.4 & 0.06 & 90.68 \\
\hline 13 & 0.26 & 19.10 & 0.02 & 16.86 & 26.09 & 0.03 & - & 2.49 & 9.25 & 17.4 & 0.06 & 91.58 \\
\hline 14 & 0.26 & 17.90 & 0.02 & 16.95 & 26.07 & 0.03 & - & 2.49 & 9.25 & 17.4 & 0.06 & 90.46 \\
\hline 15 & 0.25 & 18.40 & 0.02 & 16.99 & 26.08 & 0.03 & - & 2.49 & 9.25 & 17.4 & 0.06 & 90.99 \\
\hline
\end{tabular}

Table 2. Representative microprobe data for Mg-Fe silica phase in $\mathrm{Wt} \%$ oxides for the Njweng ridge.

\begin{tabular}{ccccccccccc}
\hline Analyses & $\mathrm{Na}_{2} \mathrm{O}$ & $\mathrm{MgO}$ & $\mathrm{Al}_{2} \mathrm{O}_{3}$ & $\mathrm{SiO}_{2}$ & $\mathrm{FeO}$ & $\mathrm{P}_{2} \mathrm{O}_{5}$ & $\mathrm{~K}_{2} \mathrm{O}$ & $\mathrm{CaO}$ & $\mathrm{Total}$ \\
\hline 1 & 0.01 & 18.03 & 0.01 & 57.41 & 23.45 & - & 0.01 & 0.67 & 99.59 \\
2 & 0.02 & 18.14 & 0.02 & 55.99 & 23.25 & 0.03 & - & 0.88 & 98.33 \\
3 & 0.01 & 17.98 & 0.01 & 55.76 & 23.51 & 0.03 & - & 0.69 & 97.99 \\
4 & 0.01 & 17.91 & 0.01 & 57.40 & 23.52 & 0.02 & 0.01 & 0.67 & 99.55 \\
5 & 0.02 & 18.11 & 0.01 & 56.01 & 23.55 & 0.03 & 0.01 & 0.89 & 98.63 \\
6 & 0.03 & 17.94 & 0.01 & 55.77 & 23.51 & 0.03 & 0.01 & 0.70 & 98.00 \\
\hline
\end{tabular}

\subsubsection{Silicate Facies BIF}

$\sum$ REE contents in both the oxide facies $\left(\sum\right.$ REE $=$ $11.92 \mathrm{ppm}$ average) and silicate facies ( $\sum \mathrm{REE}=10.59$ ppm average) of BIF from the Njweng prospect are almost similar, (the $\sum$ REE is rather seen in Table 3). There is no clear-cut relationship between $\sum$ REE and the facies of iron formation. All the samples exhibit a decrease in concentration from the LREE to HREE (average $\left.\mathrm{La} / \mathrm{Yb}_{\mathrm{PAAS}}=0.36\right)$ and a depletion of middle $\mathrm{REE}$ relatively to heavy HREE (average $\mathrm{Dy} / \mathrm{Yb}_{\mathrm{PAAS}}$ ranges from 0.92 , slightly above that of oxide facies BIFs average 0.85). REE patterns in this facies depict positive $\mathrm{Eu}$ $\left(\mathrm{Eu} / \mathrm{Eu}^{*}=2.53\right)$ and $\mathrm{Y}_{\text {PAAS }}\left(\mathrm{Y} / \mathrm{Y}^{*}=1.48\right)$ anomalies, slightly below and above that of the oxide facies respectively, while the $\mathrm{Ce}$ values $\left(\mathrm{Ce} / \mathrm{Ce}^{*}=0.81\right)$ are similar.

$\sum$ REE contents in the martite-goethite $(\sim 28.56 \mathrm{ppm}$ average) are greater than those of BIF facies $(\sim 11.25$ $\mathrm{ppm}$ average $)$ and depict positive $\mathrm{Eu}\left(\mathrm{Eu} / \mathrm{Eu}^{*}=1.55\right)$,
$\mathrm{Ce}\left(\mathrm{Ce} / \mathrm{Ce}^{*}=1.06\right)$, and $\mathrm{Y}_{\text {PASS }}\left(\mathrm{Y} / \mathrm{Y}^{*}=1.12\right)$ anomalies (Table 3 and Figure 9). REE contents in the granular and the massive bands of the oxide facies BIF are those of the structural facies that approach the martite goethite value with $15.44 \mathrm{ppm}$ and $17.07 \mathrm{ppm}$ respectively. The Ce enrichment in the ore is unique and contrasting with its depletion in the two BIFs facies.

\section{Discussion}

\subsection{Textural and Mineralogical Changes}

BIFs at Njweng are marked by alternate silica- and ironbearing bands. This texture worldwide has been intensively studied to reconstruct the chemical and physical properties of the Archean-Paleoproterozoic oceans and their changes with time [34-36]. The overall well-bedded BIF sediments found throughout the world attest to a low-energy continuous escape of hydrothermal fluids into the basin with occasional more intensive flows 
Table 3. REE (in ppm) geochemical data of the oxides and silicate facies BIF and that of the martite-goethite mineralisation of Njweng.

\begin{tabular}{|c|c|c|c|c|c|c|c|}
\hline & & & $\mathrm{BIF}$ & & & & Martite-goethite \\
\hline & & & Oxide faci & & & $c: 1 \cdot$ & \\
\hline & Granular \& massive & Massive & Granular & Specular & Weakly banded & & \\
\hline $\mathrm{La}$ & 2.00 & 3.13 & 3.73 & 1.25 & 1.03 & 1.90 & 4.27 \\
\hline $\mathrm{Ce}$ & 3.65 & 5.38 & 5.12 & 2.25 & 1.83 & 3.20 & 10.77 \\
\hline $\operatorname{Pr}$ & 0.46 & 0.71 & 0.81 & 0.33 & 0.24 & 0.43 & 1.28 \\
\hline $\mathrm{Nd}$ & 2.08 & 2.98 & 3.48 & 1.85 & 1.23 & 2.13 & 5.43 \\
\hline $\mathrm{Sm}$ & 0.43 & 0.55 & 0.65 & 0.39 & 0.26 & 0.38 & 1.11 \\
\hline $\mathrm{Eu}$ & 0.33 & 0.27 & 0.33 & 0.28 & 0.21 & 0.24 & 0.37 \\
\hline Gd & 0.62 & 0.63 & 0.75 & 0.57 & 0.42 & 0.53 & 1.12 \\
\hline $\mathrm{Tb}$ & 0.11 & 0.10 & 0.12 & 0.10 & 0.07 & 0.09 & 0.20 \\
\hline Dy & 0.69 & 0.61 & 0.74 & 0.58 & 0.49 & 0.59 & 1.37 \\
\hline $\mathrm{Y}$ & 5.95 & 4.63 & 5.93 & 5.15 & 4.23 & 5.27 & 9.00 \\
\hline Но & 0.17 & 0.13 & 0.17 & 0.14 & 0.12 & 0.14 & 0.30 \\
\hline Er & 0.50 & 0.42 & 0.52 & 0.43 & 0.37 & 0.42 & 0.98 \\
\hline $\mathrm{Tm}$ & 0.08 & 0.06 & 0.08 & 0.07 & 0.06 & 0.07 & 0.14 \\
\hline $\mathrm{Yb}$ & 0.49 & 0.40 & 0.50 & 0.40 & 0.36 & 0.39 & 1.08 \\
\hline $\mathrm{Lu}$ & 0.07 & 0.06 & 0.07 & 0.07 & 0.06 & 0.06 & 0.16 \\
\hline$\sum \mathrm{REE}$ & 11.65 & 15.44 & 17.07 & 8.68 & 6.77 & 10.59 & 28.56 \\
\hline$\sum \mathrm{REEY}$ & 17.60 & 20.07 & 23.00 & 13.83 & 11.00 & 15.85 & 37.56 \\
\hline $\mathrm{Eu} / \mathrm{Eu}^{*}$ & 2.99 & 2.13 & 2.26 & 2.76 & 2.96 & 2.53 & 1.55 \\
\hline $\mathrm{Ce} / \mathrm{Ce}^{*}$ & 0.88 & 0.84 & 0.68 & 0.81 & 0.84 & 0.81 & 1.06 \\
\hline $\mathrm{Y} / \mathrm{Y}^{*}$ & 1.41 & 1.47 & 1.34 & 1.45 & 1.41 & 1.48 & 1.12 \\
\hline avg $\mathrm{La} / \mathrm{Yb}_{\text {pass }}$ & 0.30 & 0.35 & 0.55 & 0.23 & 0.21 & 0.36 & 0.29 \\
\hline avg $\mathrm{La} / \mathrm{Sm}_{\text {pass }}$ & 0.68 & 0.75 & 0.84 & 0.47 & 0.57 & 0.72 & 0.56 \\
\hline avg $\mathrm{Dy} / \mathrm{Yb}_{\mathrm{PAAS}}$ & 0.85 & 0.81 & 0.90 & 0.87 & 0.82 & 0.92 & 0.76 \\
\hline avg $\mathrm{Sm} / \mathrm{Yb}_{\text {paas }}$ & 0.44 & 0.47 & 0.66 & 0.50 & 0.37 & 0.50 & 0.52 \\
\hline avg $\mathrm{Eu} / \mathrm{Sm}_{\text {paas }}$ & 3.93 & 3.70 & 2.64 & 3.62 & 4.10 & 3.26 & 1.70 \\
\hline avg $\mathrm{Gd} / \mathrm{Yb}_{\text {paas }}$ & 0.76 & 0.76 & 0.91 & 0.85 & 0.71 & 0.83 & 0.63 \\
\hline avg $\mathrm{Y} / \mathrm{Ho}_{\text {pas }}$ & 1.32 & 1.38 & 1.31 & 1.35 & 1.33 & 1.41 & 1.10 \\
\hline
\end{tabular}

which created the sedimentary structures [36]. This compositional banding has been interpreted as representing the original sedimentary features [37]. In Mbalam, it has been considered as the only preserved sedimentary feature in the itabirite [38]. The itabirite facies are generally considered to be protore of high grade iron ore [21].

The processes of upgrading BIF to iron ore have remained contentious despite the recent progress made to elucidate them $[21,39-42]$ due to the search for proof in identifying the processes responsible for the increase of iron in the ore. Banding relicts in the martite-goethite with microsagging structures indicative of compaction is a strong indicator of the supergene weathering that permits to obtain high grade mineralization $[21,43]$. Thus this fact points to supergene enriched mineralization in the study area. Similar interpretations of bedded martitegoethite ore bodies in the Hamersley province resulting from the supergene alteration of precursor BIF have been noted [44].

\subsection{Changes in Mineral Assemblages}

Microscopic observations have revealed that, most of the magnetite crystals are granoblastic and porphyroblastic with voids that exhibit a poikilitic texture, some rare 


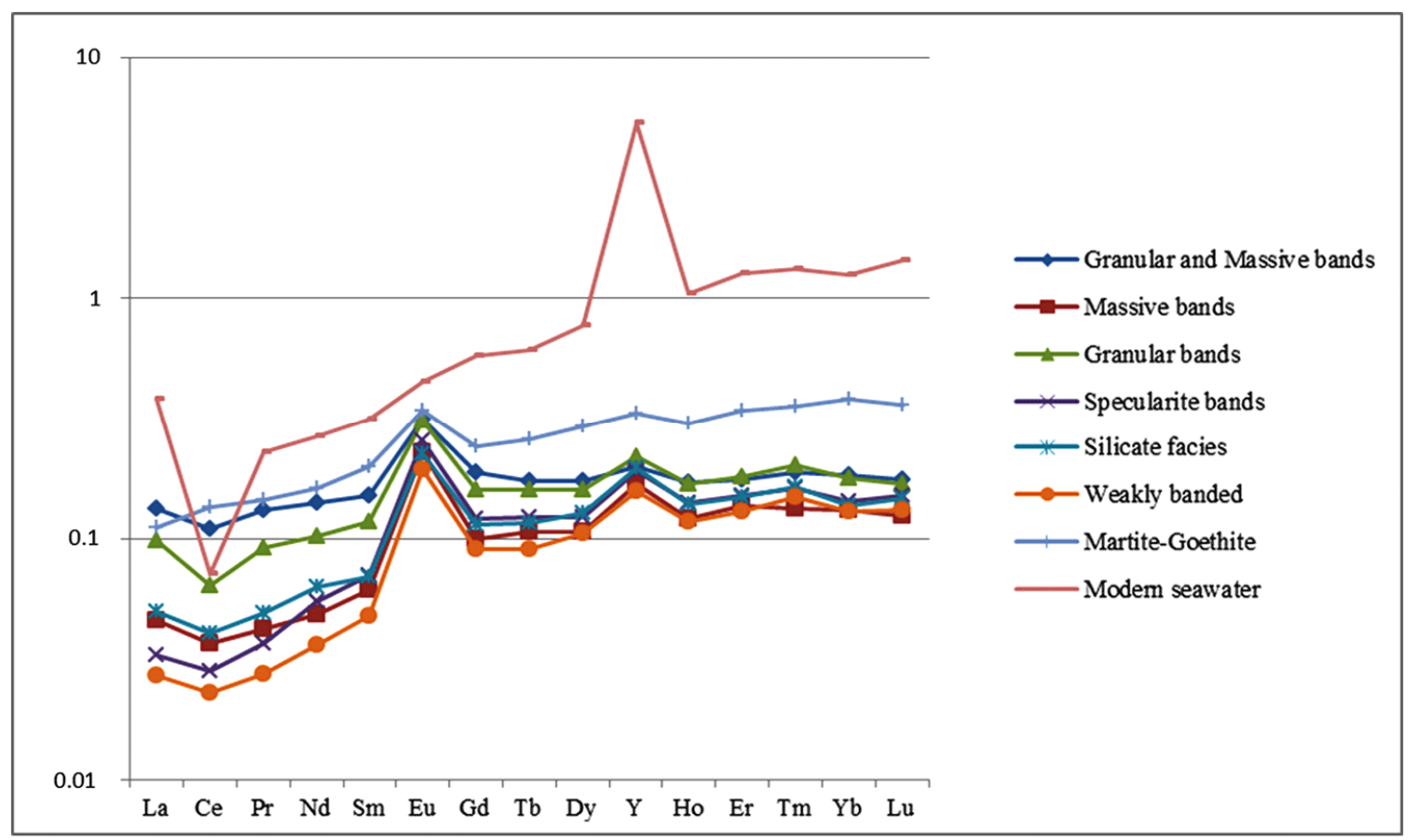

Figure 9. Average (Av) values of BIF facies, Enriched martite goethite mineralization, and modern seawater REE normalized against the Post-Archean Australian Shale. BIFs and enriched martite-goethite are plods in ppm while modern seawater is plotted in (pmol/kg).

quartz, monazite and apatite inclusions. Quartz inclusions are commonly subhedral suggesting that these BIFs have been metamorphosed and their shape is a product of post-depositional recrystallization [45]. The ubiquitous presence of quartz in magnetite has significance with regards to the development of layering in the BIF. It is here suggested that the BIF was initially essentially cherty with dispersed $\mathrm{Fe}$ that aggregated and grew into large crystals during diagenesis [45].

Regardless of the iron oxides sequence in banding, it clearly appears that magnetite is an early oxide phase in the alteration paragenesis. Reflected light photomicrographs of BIF and enriched martite-goethite mineralization show abundant euhedral crystals (octahedral and/or dodecahedral crystals). This crystal habit is very common for magnetite, and suggests that the hematite is pseudomorph after magnetite, an occurrence referred to as "martite" [46]. This observation indicates that all the BIF samples in this study have undergone considerable secondary oxidation and supergene enrichment. It can then be concluded on the basis of detailed microscopic observations of our samples that magnetite is the primary oxide, and hematite is the result of supergene processes of the magnetite alteration. Two paragenetic sequences are observed here: the first and dominant process is the direct transformation from the primary magnetite to martite by oxidation (Figure 6(a)). Such zoning was observed in previous studies and was considered as the result of chemical weathering [47]. In the second par agenetic se- quence, the magnetite is first transformed into goethite by hydration then into martite by dehydration (Figure 5(c)) [48]. These dual transformations of the magnetite directly into martite and/or indirectly via goethite highlight the unstable conditions that governed the breakdown of the primary magnetite. Trellis interlobate, and some polygonal forms of martite exhibit intragranular secondary porosity both in barren and enriched rocks. This is materialized by relict sharp euhedral voids, mainly due to silica leaching and other trace minerals such as sulphides [49]. It is accompanied by widespread oxidation of magnetite into martite; although, it is not possible at this stage to determine the timing of such porosity developing within the martite grains. Some porosity within martite is likely to form as a result of the primary oxidation of magnetite to martite [49]. Apart from the hematite pseudomorph after magnetite, iron-rich layers in some BIF sections show alternate magnetite and hematite thin bands. These particular alternate magnetite-hematite bands in the iron bands of the oxide facies have been suggested as deriving from the direct precipitation of each of these oxides from the hydrothermal solution [50]. However, the presence of magnetite relicts in the martite grains, and within the martite bands at Njweng instead suggests weathering that is following the weakness plane of banding. This also suggested the involvement of an intermediate phase of iron hydroxides, hence the weathering affecting the original magnetite crystals [50-54]. 


\subsection{REE Anomalous Behaviour and Original Composition of Seawater}

Taken globally, REEY PAAS patterns of the oxide and silicate facies BIF and the martite-goethite mineralization of the Njweng ridge (Table 3) are characterized by a low $\sum$ REE, a strong depletion in LREE relatively compared to HREE (Figure 9). Iron formations display LREE depletion pattern similar to that of modern deep-marine water with no terrigenous input [12]. A similar trend is observed between the average Njweng BIFs and limestone, with depletion of LREE relatively to HREE. This HREE enrichment is a feature of modern seawater $[55,56]$ (Figures 9 and 10), and spider diagrams for the average pacific seawater confirm this fact (Figure 9). If we cast our gaze even further back, it would appear that HREE enrichment has been a feature of seawater since at least the late Archaean $[57,58]$ and it corroborates with the spider diagram of BIF and enriched martite-goethite. Although far more subtle, but possibly significant changes to HREE fractionation cannot be ruled out [6]. It has been suggested that, the small ionic radii of these elements result in stronger complexes which tend to stabilize them in solution giving them a stronger complexation $[59,60]$. Their stronger inorganic complexation makes them to be more stabilized in solution, which is why they are more abundant in seawater compared to the marine clastic sediments. The overall shape of REE pattern is similar to that of limestone $[23,24]$ considered as being proxy material of modern seawater (Figure 10). Mineralogical changes could in addition increase the REE abundance during weathering. The release of some elements in REE-rich minerals such as monazite and apatite that have been identified in some samples (Figure 7) may be responsible for the high REE content in some samples of BIF or have incorporated, hence causes the retention of REE released during diagenetic crystallization of the original iron formation. Similar effects were observed in some iron formations with other REE-rich minerals such as apatite, and xenotime [61,62]. As such, their high abundance in some samples would raise difficulties in sampling for the REE in order to determine the origin of the BIF from these elements. REE contents of BIF are low when compared to the enriched martite-goethite suggesting an enrichment of these elements with phase transformations. The positive Ce anomaly obtained in the martite-goethite also supports this fact (Figure 9).

\subsection{Europium Anomalies}

Figure 10 depicts positive Eu anomalies in both Njweng BIF facies and enriched martite-goethite as well as in limestone. The presence of a positive $\mathrm{Eu}$ anomaly in many Archean and Proterozoic iron-formation REE patterns was suggested to be the result of the input from suboceanic hydrothermal solutions from deep-sea spreading centres into ocean waters (which are considered as the source of the iron as well as of $\mathrm{SiO}_{2}$ of the iron-formations) [63-65]. The positive $\mathrm{Eu}$ anomalies also indicate the reducing conditions prevailing during the deposition of this formation. It has been shown that, reduction of $\mathrm{Eu}$ does not seem to occur within the ocean basins except by hydrothermal systems $[66,67]$. The Eu anomaly in both BIF facies and enriched martite-goethite mineralization might thus indicate an input of strongly reducing hydrothermal solutions into the water from which the BIF precipitated as demonstrated in other areas $[6,13,62,68$,$] . The$ strong positive $\mathrm{Eu}$ anomalies in the BIFs may only result

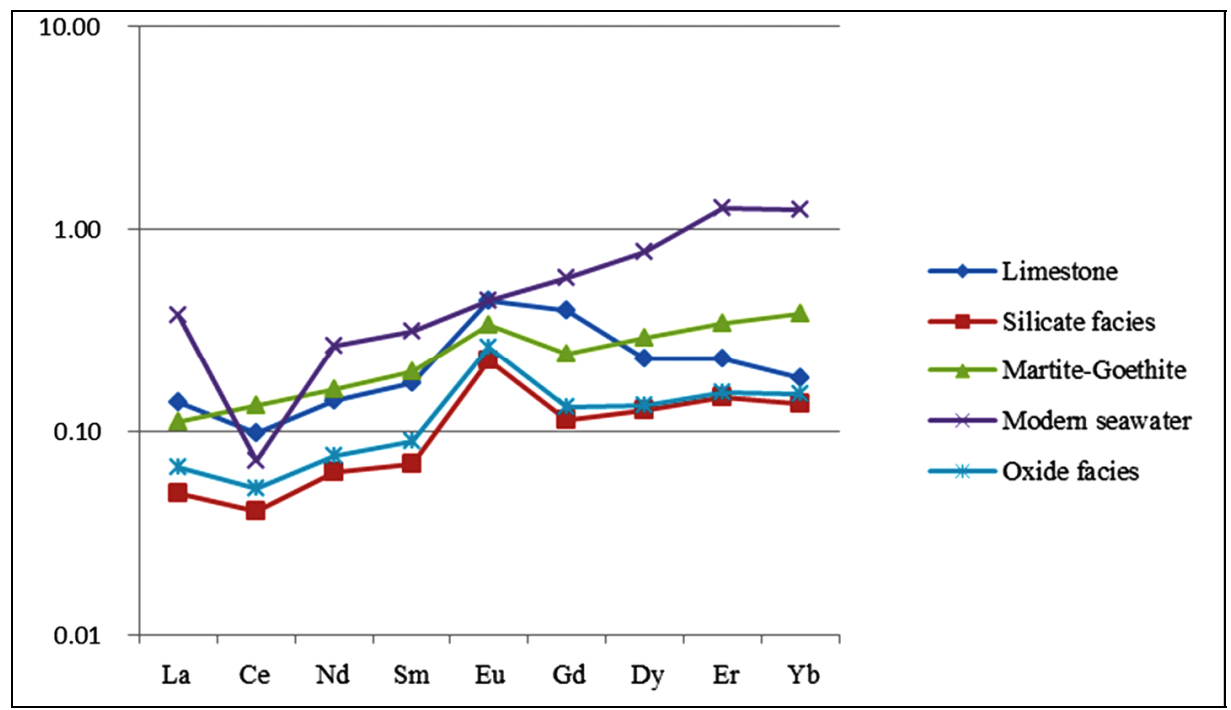

Figure 10. Average (Av) REE values of BIF, enriched martite-goethite mineralization from Njweng, and Limestone, and modern seawater normalized against the Post-Archean Australian Shale. BIFs and enriched martite-goethite are plotted in ppm while modern seawater is in (pmol/kg). 
from an input of Eu-enriched hydrothermal fluids into the water column $[12,13,68-70]$. The disparate behaviour of Eu from neighbouring REEs under hydrothermal conditions is attributed to the reduction of $\mathrm{Eu}$ (III) under high temperature $\left(250^{\circ} \mathrm{C}\right)$ and low Eh conditions [71]. Based on REEY anomalies obtained from Njweng samples, it is suggested that the BIF was formed by precipitation and deposition from mixed Precambrian seawater and hydrothermal fluids.

When compared with the study area BIF and enriched martite-goethite mineralization, modern seawater spider diagram (Figure 9) does not typically display Eu anomaly. The absence of Eu anomaly is a feature of modern seawater, except in near hydrothermal vents $[55,56]$. The Eh for this system decreases with increasing $\mathrm{pH}$, but will always be well above the redox potential for the stability of divalent $\mathrm{Eu}$. Thus, $\mathrm{Eu}^{2+}$ cannot exist in the depositional environment where the iron-formations were deposited. Thus Eu in iron-formations may not have been fractionated on the grounds of redox conditions from the other REE. Therefore, $\mathrm{Eu}$ anomalies in iron-formations may not give any indication of the composition of the atmosphere during the Precambrian.

\subsection{Yttrium Anomalies}

In addition, $\mathrm{Y}$ is an element generally found in fluid-related alkaline volcanic rocks, and the positive $\mathrm{Y}$ anomaly apart from the $\mathrm{Eu}$ anomaly may suggest a volcanic input [72]. The $\mathrm{Y}$ anomaly observed is due to $\mathrm{Y} / \mathrm{Ho}$ fractionation that occurs when REE are transported as aqueous complexes. This characteristic is observed in plotted modern seawater data and limestone (Figures 9 and 10) that were respectively considered as indicators of modern and ancient seawater.

\subsection{Cerium Anomalies}

Figure 9 displays negative Ce anomalies for the Njweng BIF, limestone, and modern seawater. The interpretation of $\mathrm{Ce}$ anomalies in BIFs is made difficult by the complex redox behaviour of $\mathrm{Ce}$. As observed at Njweng, the presence of negative $\mathrm{Ce}$ anomalies in BIF samples is well established [12,62,73-76]. This implies oxidation and segregation of $\mathrm{Ce}$ as $\mathrm{Ce}(\mathrm{IV})$. Negative $\mathrm{Ce}$ anomalies are suggested to be good evidence of the influence of seawater with a REE pattern similar to modern seawater [56, 77]. It has long been suggested that the negative Ce anomaly in seawater reflects the oxidation of $\mathrm{Ce}^{3+}$ to much more insoluble $\mathrm{Ce}^{4+}[78,79]$. This oxidation generally takes place under some specific $\mathrm{pH}$ and $\mathrm{Eh}$ conditions ( $\mathrm{pH}=8, \mathrm{E}_{\mathrm{h}}=0.15-0.45$ volt) $[66]$ and is a common result of weathering. Recent works on negative $\mathrm{Ce}$ anomaly suggested microbial and abiotic origins for this element $[62,80-82]$. The range of $\mathrm{Ce}$ anomalies observed in
BIFs may result from variable mixing and oxidation processes on an ocean wide scale, or perhaps mostly local processes, including diagenetic recycling as noted in other areas $[83,84]$. Ce anomalies in iron formations can also arise from analytical artefacts and diagenetic alteration. Therefore, it might reflect metamorphic or recent weathering-related redistribution of REEs between metamorphic minerals and compositionally different layers or between the soil horizon and bedrock $[85,86]$.

The enriched martite-goethite mineralization shows a positive $\mathrm{Ce}$ anomaly, contrasting with the negative $\mathrm{Ce}$ anomaly observed in the BIF at Njweng. This difference could derive from enrichment in REE minerals during weathering, which resulted in enrichment of all the REEs (Figure 9). Monazite alteration in BIF samples increases $\mathrm{Ce}$ in enriched martite-goethite, producing a positive anomaly $[61,62]$. However, for the reasons given above, the lack of such anomalies in an iron formation does not necessarily imply that seawater was not depleted in Ce.

It is known that, the modern oceans receive most of their REEs from three sources: the dissolved loads of rivers $[87,88]$, hydrothermal alteration of the oceanic crust [89], and sediments undergoing diagenesis. Moreover, iron formation REE are chemical precipitated fraction related to the REE of the iron source materials, that of the seawater and both [90]. It's therefore evident to consider that REE in BIF may not be considered as proxy material of seawater. In addition to this, changes by enrichment or depletion during weathering and metamorphism are also to be considered. This leads to the conclusion that the REE pattern of an iron formation does not appear to be a useful indicator of the REE pattern of seawater of the same age [90]. Based on this river loads arguments, it becomes reasonable to expect the REE pattern of Archean "seawater" to be different from that of modern seawater since there is no evidence of their precipitation from a solution dominated by seawater of the same age [90].

\section{Conclusions}

Two main facies of BIF are distinguishable at Njweng: the oxide and the silicate facies. Banding is the main preserved sedimentary feature in the BIF. Petrographic evidence for quartz recrystallization is eloquent proof that banding in the BIF is a post depositional feature. The interruption of continuous banding in itabirite is due to the combined sedimentary and metamorphic processes. The subhedral quartz inclusions prove that the BIFs have been metamorphosed. On the basis of the detailed microscopic observation of our samples it is concluded that magnetite is the primary oxide and it is highly affected by two transformation phases: martitization through oxidation into martite with preservation of the trellis texture of the original magnetite, and hydration into goethite 
followed by dehydration into martite. Relict banding in the enriched martite-goethite mineralization points to secondary oxidation and supergene enrichment that have affected the BIF. The presence of abundant pores and banding relicts observable in polished thin sections, accompanied by widespread oxidation, indicate the removal of silica by direct leaching and the formation of the enriched martite-goethite mineralization.

The Eu anomaly observed are the results of inputs from strongly reducing sub-oceanic hydrothermal solutions from deep-sea spreading centres into ocean waters, as well as a higher heat flow in the oceanic crust during the Archaean. In addition to this anomaly, the positive $\mathrm{Y}$ anomaly combined with that of $\mathrm{Eu}$, and the $\mathrm{Y} / \mathrm{Ho}$ ratio obtained, point to volcanic input in the BIF formation, and REE transportation by aqueous complexes. The LREE depletion, HREE enrichment and positive Eu anomaly showed that, BIFs were formed by precipitation and deposition from mixed Precambrian seawater and hydrothermal fluids of late Archean to early Proterozoic age. The negative $\mathrm{Ce}$ anomalies are due to increasing $\mathrm{Ce}$, resulting from microbial and abiotic processes, and attests to the strongly oxidizing conditions in the marine environment. Positive $\mathrm{Ce}$ anomalies in the martite-goethite derived from enrichment in REE minerals during weathering. This complex behaviour of $\mathrm{Ce}$ does not allow $\mathrm{Ce}$ to be considered as indicative of seawater conditions. The change in REE abundance derived from change in seawater composition, various diagenetic or progressive alterations of REE contents with increasing geological time and also reflects the existence of REE-rich minerals such as monazite and apatite.

\section{Acknowledgements}

This paper is an integral part of the senior author's Ph.D thesis at the University of Yaounde I, Cameroon. We gratefully acknowledge the Cameroon Iron Ore (CamIron) for their logistic support and their permission to work within their permit area. The analytical part of the study was possible thanks to the internship placement offered by CamIron and the facilities of the Mineral Resources Institute (MRI) of the Technical University of Clausthal in Germany through Prof. Bernd Lehmann. This thesis is part of the collaboration between the University of Buea and the MRI (Iron ore deposits in the Precambrian mineral belt of Cameroon) funded by the Alexander von Humboldt Foundation (AvH) and the support from them is gratefully acknowledged.

\section{REFERENCES}

[1] M. Bau, "Scavenging of Dissolved Yttrium and Rare Earths by Precipitating Iron Oxyhydroxide: Experimental Evidence for Ce, Y-Ho Fractionation, and Lanthanide
Tetrda Effect," Geochemica et Cosmochimica Acta, Vol. 63, No. 1, 1999, pp. 67-77.

doi:10.1016/S0016-7037(99)00014-9

[2] A. Knappe, P. Moller, P. Dulski and A. Pekdeger, "Positive Gadolium Anomaly in Surface Water and Ground Water of the Urban Area Berlin, Germany," Chemie der Erde, Vol. 65, No. 2, 2005, pp. 167-189. doi:10.1016/j.chemer.2004.08.004

[3] T. Akagi, F. F. Fu and S. Yabuki, "Absence of Ce Anomaly in the REE Patterns of Peat Moss and Peat Grass in the Ozegahara Peatland," Geochemical Journal, Vol. 36, No. 2, 2002, pp. 113-118. doi:10.2343/geochemj.36.113

[4] E. D. Goldberg, M. Koide and R. H. Schmitt, "Rare Earth Distributions in Marine Environment," Journal of Geophysical Research, Vol. 68, 1963, pp. 4209-4217. doi:10.1029/JZ068i014p04209

[5] D. Z. Piper, "Rare Earth Elements in the Sedimentary Cycle: A Summary," Chemical Geology, Vol. 14, No. 4, 1974, pp. 285-343. doi:10.1016/0009-2541(74)90066-7

[6] M. Bau and P. Möller, "Rare Earth Element Systematics of the Chemically Precipitated Component in Early Precambrian Iron-Formations and the Evolution of the Terrestrial Atmosphere-Hydrosphere-Lithosphere System," Geochimica et Cosmochimica Acta, Vol. 57, No. 10, 1993, pp. 2239-2249. doi:10.1016/0016-7037(93)90566-F

[7] R. Bolhar, A. Hofmann, J. Woodhead, J. Hergt and P. Dirks. "Pb- and Nd Isotope Systematics of Stromatolitic Limestones from the $2.7 \mathrm{Ga}$ Ngezi Group of the Belingwe Greenstone Belt: Constraints on Timing of Deposition and Provenance," Precambrian Research, Vol. 114, No. 3-4, 2002, pp. 277-294. doi:10.1016/S0301-9268(01)00229-7

[8] R. Bolhar, B. S. Kamber, S. Moorbath, C. M. Fedo and M. J. Whitehouse, "Characterisation of Early Archaean Chemical Sediments by Trace Element Signatures," Earth and Planetary Science Letters, Vol. 222, No. 1, 2004, pp. 43-60. doi:10.1016/j.eps1.2004.02.016

[9] G. A. Shields and G. R. Webb, "Has the REE Composition of Seawater Changed over Geological Time?" Chemical Geology, Vol. 204, No. 1-2, 2004, pp. 103-107. doi:10.1016/j.chemgeo.2003.09.010

[10] M. J. Van Kranendonk, G. E. Webb and B. S. Kamber, "New Geological and Trace Element Evidence from 3.45 Ga Stromatolitic Carbonates in the Pilbara Craton: Support of a Marine, Biogenic Origin and for a Reducing Archaean Ocean," Geobiology, Vol. 1, No. 2, 2003, pp. 91108. doi:10.1046/j.1472-4669.2003.00014.x

[11] G. E. Webb and B. S. Kamber, "Rare Earth Elements in Holocene Reefal Microbialites: A New Shallow Seawater Proxy," Geochimica et Cosmochimica Acta, Vol. 64, No. 9, 2000, pp.1557-1565.

[12] C. Klein and N. J. Beukes, "Geochemistry and Sedimentology of a Facies Transition from Limestone to Iron-Formation Deposition in the Early Proterozoic Transvaal Supergroup, South Africa." Economic Geology, Vol. 84, No. 7, 1989, pp. 1733-1774. doi: $10.2113 /$ gsecongeo.84.7.1733

[13] L. A. Derry, and S. B. Jacobsen, "The Chemical Evolu- 
tion of Precambrian Seawater-Evidence from REEs in Banded Iron Formations," Geochimica et Cosmochimica Acta, Vol. 54, No. 11, 1990, pp. 2965-2977. doi:10.1016/0016-7037(90)90114-Z

[14] M. Bau and, P. Dulski, "Distribution of Yttrium and Rare-Earth Elements in the Penge and Kuruman IronFormations, Transvaal Supergroup, South Africa," Precambrian Research, Vol. 79, No. 1, 1996, pp. 37-55. doi:10.1016/0301-9268(95)00087-9

[15] R. Frei, P. S. Dahl, E. F. Duke, K. M. Frei, T. R. Hansen, M. M. Frandsson and L. S. Jensen, "Trace Element and Isotopic Characterization of Neoarchean and Paleoproterozoic Iron Formations in the Black Hills (South Dakota, USA): Assessment of Chemical Change During 2.9 - 1.9 Ga Deposition Bracketing the 2.4 - 2.2 Ga First Rise of Atmospheric Oxygen," Precambrian Research, Vol. 162, No. 3-4, 2008, pp. 441-474. doi:10.1016/j.precamres.2007.10.005

[16] A. Bekker, J. F. Slack, N. Planavsky, B. Krapež, A. Hofmann, K. O. Konhauser and O. J. Rouxel, "Iron Formation: The Sedimentary Product of a Complex Interplay Among Mantle, Tectonic, Oceanic and Biospheric Processes," Economic Geology, Vol. 105, No. 3, 2010, pp. 467-508. doi:10.2113/gsecongeo.105.3.467

[17] Y. Kato, I. Ohta, T. Tsunematsu, Y. Watanabe, Y. Isozaki, S. Maruyama and N. Imai, "Rare Earth Elements Variations in Mid-Achean Banded Iron Formations: Implications for the Chemistry of Ocean and Plate Tectonics," Geochimica et Cosmochimica Acta, Vol. 62, No. 21-22, 1998, pp. 3475-3496. doi:10.1016/S0016-7037(98)00253-1

[18] J. Dymond, J. B. Corliss, G. R. Heath, C. W. Field, E. J. Dasch and H. H. Vieh, "Origin of Metalliferous Sediments from the Pacific Ocean," Geological Society of America Bulletin, Vol. 84, No. 10, 1973, pp. 3355-3372. doi:10.1130/0016-7606(1973)84<3355:OOMSFT $>2.0$.C $\underline{\mathrm{O} ; 2}$

[19] R. M. Sherrell, M. P. Field and G. Ravizza, "Uptake and Fractionation of Rare Earth Elements on Hydrothermal Plume Particles at $9^{\circ} 45^{\prime} \mathrm{N}$, East Pacific Rise," Geochimica et Cosmochimica Acta, Vol. 63, No. 11-12, 1999, pp. 1709-1722. doi:10.1016/S0016-7037(99)00182-9

[20] G. B. Morey, "High-Grade Iron Ore Deposits of the Mesabi Range, Minnesota: Products of a Continental-Scale Proterozoic Ground-Water Flow System," Economic Geology, Vol. 94, No. 1, 1999, pp. 133-142. doi:10.2113/gsecongeo.94.1.133

[21] D. Taylor, H. J. Dalstra, A. E. Harding, G. C. Broadbent, and M. E. Barley, "Genesis of High-Grade Hematite Ore Bodies of the Hamersley Province, Western Australia," Economic Geology, Vol. 96, No. 4, 2001, pp. 837-873.

[22] J. Zhang and Y. Nozaki, "Rare Earth Elements and Yttrium in Seawater: ICP-MS Determinations in the East Caroline, Coral Sea, and South Fiji Basins of the Western South Pacific Ocean," Geochemica et Cosmochimica Acta, Vol. 60, No. 23, 1996, pp. 4631-4644. doi:10.1016/S0016-7037(96)00276-1

[23] B. Jacobsens and M. R. Pimentel-Klose, "A Nd Isotopic Study of the Hamersley and Michipicoten Banded Iron
Formations: The Source of REE and Fe in Archean oceans," Earth and Planetary Science Letters, Vol. 87, No. 1-2, 1988, pp. 29-44. doi:10.1016/0012-821X(88)90062-3

[24] B. Jacobsens and M. R. Pimentel-Klose, "Nd Isotopic Variations in Precambrian Banded Iron Formations," Geophysical Research Letters, Vol. 15, No. 4, 1988, pp. 393-396. doi:10.1029/GL015i004p00393

[25] S. F. Toteu, J. Penaye and Y. P. Djomani, "Geodymanic Evolution of the Pan-African Belt in Central Africa with Special Reference to Cameroon," Canadian Journal of Earth Sciences, Vol. 41, No. 1, 2004, pp. 73-85. doi: $10.1139 / \mathrm{e} 03-079$

[26] H. Mvondo, S. Owona, J. Mvondo Ondoa and J. Essono, "Tectonic Evolution of the Yaounde Segment of the Neoproterozoic Central African Orogenic Belt in Southern Cameroon," Canadian Journal of Earth Sciences, Vol. 44, No. 4, 2007, pp. 433-444. doi:10.1139/e06-107

[27] C. E. Suh, A. R. Cabral and E. Ndime, "Geology and Ore Fabrics of the Nkout High-Grade Haematite Deposit, Southern Cameroon," In: T. Angerer, S. Hagemann, C. A. Rosière, Eds., The Origin of Enriched Iron and Manganese Ore Deposits, Smart Science for Exploration and Mining, Townsville, 2009, pp. 558-560.

[28] C. K. Shang, W. Siebel, M. Satir, F. Chen and J. O. Mvondo, "Zircon $\mathrm{Pb}-\mathrm{Pb}$ and U-Pb Systematics of TTG Rocks in the Congo Craton: Constraints of Crustal Formation, Crystallization and Pan-African Lead Loss," Bulletin Geosciences, Vol. 79, No. 4, 2004, pp. 205-219.

[29] R. Tchameni, K. Mezger, N. E. Nsifa and A. Pouclet, "Crustal Origin of Early Proterozoic Syenites in the Congo Craton (Ntem complex), South Cameroon," Lithos, Vol. 57, No. 1, 2001, pp. 23-42. doi:10.1016/S0024-4937(00)00072-4

[30] S. F. Toteu, W. R. Van Schmus, J. Penaye and J. B. Nyobe " $\mathrm{U} / \mathrm{Pb}$ and $\mathrm{Sm} / \mathrm{Nd}$ Evidence for Eburnean and Pan-African High-Grade Metamorphism in Cratonic Rocks of Southern Cameroon," Precambrian Research, Vol. 67, No. 3-4, 1994, pp. 321-347. doi:10.1016/0301-9268(94)90014-0

[31] M. Caen Vachette, Y. Vialette, J.-P. Bassot and P. Vidal, "Apport de la Géochronologie à la Connaissance de la Géologie Gabonaise," Chronique de la Recherche Minière, Vol. 491, 1988, pp. 35-54.

[32] Sundance Resources Limited. http://intranet/SitePages/Default.aspx

[33] S. R. Taylor and S. M. McLennan, "The Continental Crust: Its Composition and Evolution," Blackwell, Oxford, 1985, p. 312.

[34] E. A. Gaucher, et al., "Palaeotemperature Trend for PreCambrian Life Inferred from Resurrected Proteins," Nature, Vol. 451, No. 7179, 2008, pp. 704-707. doi: $10.1038 /$ nature 06510

[35] F. Robert and M. Chaussidon, "A Paleotemperature Curve for the Precambrian Oceans Based on Silicon Isotopes in Cherts," Nature, Vol. 443, No. 7036, 2006, pp. 969-972. doi:10.1038/nature05239

[36] Z. Lewy, "Banded Iron Formations (BIFs) and Associated 
Sediments Do Not Reflect the Physical and Chemical Properties of Early Precambrian Seas," International Journal of Geosciences, Vol. 3, No. 1, 2012, pp. 226-236. doi:10.4236/ijg.2012.31026

[37] A. F. Trendall and J. G. Blockley, "The Iron Formations of the Precambrian Hamersley Group, Western Australia," Geological Survey of Western Australia Bulletin, Vol. 119, 1970, pp. 1-366.

[38] J. M. Allen and M. P. Simpson, "Petrography of Metamorphosed Banded Iron Formation and Associated Schists from the Mbarga Iron Deposit, Mbalam Project Area, Republic of Cameroon," John Allen and Associates Ltd Report (Unpublished), 2008, p. 45.

[39] N. H. S. Olivier, J. S. Cleverley, G. M. Dipple and G. C. Broadbent, "Giant BIF Hosted Haematite Ores: Geochemical and Isotopic Modelling of Meteoric and Basinal Fluid-Rock Reactions," Proceedings of Biennial Meeting of the Society for Geology Applied to Mineral Deposits, Dublin, 2007, pp. 1219-1222.

[40] A. D. Weeb, G. R. Dicksens and N. H. S. Oliver, "From Banded Iron-Formation to Iron Ore: Geochemical and Mineralogical Constraints from across the Hamersley Province, Western Australia," Chemical Geology, Vol. 197, No. 1-4, 2003, pp. 215-251. doi:10.1016/S0009-2541(02)00352-2

[41] W. S. Thorn, G. C. Hagemann and M. E. Barley, "Petrographic and Geochemical Evidence for Hydrothermal Evolution of the North Deposits, Mt. Tom Price, Western Australia," Mineralium Deposita, Vol. 39, No. 7, 2004, pp. 766-783. doi:10.1007/s00126-004-0444-X

[42] R. C. Figueiredo e Silva, S. C. Hagemann, L. M. Lobato, and T. Venermann, "Iron Oxide Paragenesis Quartz Vein Chronology and Hydrothermal Fluid Evolution at the Giant North Range Carajás Iron Deposits in Brazil," Proceedings of the 9th Biennial Meeting of the Society for Geology Applied to mineral Deposits, Dublin, 2007, pp. 1223-1226.

[43] R. C. Morris, "Genesis of Iron Ore in Banded Iron-Formation by Supergene and Supergene Metamorphic Processes-A Conceptual Model," In: K. H. Wolff, Ed., Handbook of Strata-Bound and Stratiform ore Deposits, Elsevier, Amsterdam, 1985. pp. 73-235.

[44] J. M. F. Clout, "Upgrading Processes in BIF-Derived Iron Ore Deposits-Implication for Ore Genesis and Downstream Processing," Proceedings of Iron Ore 2002 Conference, Perth, 9-11 September 2002, pp. 237-241.

[45] C. Klein and Bricker, "Some Aspects of the Sedimentary and Diagenetic Environment of Proterozoic Banded IronFormation," Economic Geology, Vol. 72, No. 8, 1977, pp. 1457-1470. doi:10.2113/gsecongeo.72.8.1457

[46] C. Klein and E. A. Ladeira "Petrography and Geochemistry of the Least Altered Banded Iron-Formation of the Archean Carajás Formation, Northern Brazil," Economic Geology, Vol. 97, No. 3, 2002, pp. 643-651.

[47] C. A. Rosiere, "Strukturelle und Texturelle Untersuchungen in der Eisenerzlagerstaette 'Pico de Itabira', bei Itabirito, Minas Gerais," Brasilien: Claustheler Geowissenschaftliche Dissertationen, Vol. 9, 1981, p. 302.

[48] R. C. Morris, "A Textural and Mineralogical Study of the
Relationship of Iron Ore to Banded Iron Formation in the Hamersley Iron Province of Western Australia," Economic Geology, Vol. 75, No. 2, 1980, pp. 184-209. doi:10.2113/gsecongeo.75.2.184

[49] B. L. Davis, G. J. Rapp and M. J. Walawender, "Fabric and Structural Characteristics of the Martitization Process," American Journal of Science, Vol. 266, No. 6, 1968, pp. 482-496. doi:10.2475/ajs.266.6.482

[50] R. C. Morris, "Genetic Modelling for Banded Iron-Formation of the Hamersley Group, Pilbara Craton, Western Australia," Precambrian Research, Vol. 60, No. 1-4, 1993, pp. 243-286. doi:10.1016/0301-9268(93)90051-3

[51] A. Kappler, C Pasquero, K. O. Konhauser and D.K. Newman, "Deposition of Banded Iron Formations by Anoxygenic Phototrophic Fe(II)-Oxidizing Bacteria," Geology, Vol. 33, No. 11, 2005, pp. 865-868. doi:10.1130/G21658.1

[52] K. O. Konhauser, et al., "Decoupling Photochemical Fe(II) Oxidation from Shallow-Water BIF Deposition," Earth and Planetary Science Letters, Vol. 258, No. 1-2, 2007, pp. 87-100. doi:10.1016/j.epsl.2007.03.026

[53] H. P. Eugster and I.-M. Chou, "The Depositional Environments of Precambrian Banded Iron-Formations," Economic Geology, Vol. 68, No. 7, 1973, pp. 1144-1168. doi:10.2113/gsecongeo.68.7.1144

[54] P. S. Braterman, A. G. Cairns-Smith and R. W. Sloper, "Photooxidation of Hydrated $\mathrm{Fe}^{2++}$ Significance for Banded Iron Formations," Nature, Vol. 303, No. 5913, 1983, pp. 163-164. doi:10.1038/303163a0

[55] H. Elderfield and M. J. Greaves, "The Rare Earth Elements in Seawater," Nature, Vol. 296, No. 5854, 1982, pp. 214-219. doi: $10.1038 / 296214 \mathrm{a} 0$

[56] H. J. W. De Baar, M. P. Bacon, P. G. Brewer and K. W. Bruland, "Rare Earth Elements in the Pacific and Atlantic Oceans," Geochimica et Cosmochimica Acta, Vol. 49, No. 9, 1985, pp. 1943-1959. doi:10.1016/0016-7037(85)90089-4

[57] M. Bau and P. Dulski, "Distribution of Yttrium and RareEarth Elements in the Penge and Kuruman Iron-Formations, Transvaal Supergroup, South Africa," Precambrian Research, Vol. 79, No. 1, 1996, pp. 37-55. doi:10.1016/0301-9268(95)00087-9

[58] B. S. Kamber and G. E. Webb, "The Geochemistry of Late Archaean Microbial Carbonate: Implications for Ocean Chemistry and Continental Erosion History," Geochimica et Cosmochimica Acta, Vol. 65, No. 15, 2001, pp. 2509- 2525. doi:10.1016/S0016-7037(01)00613-5

[59] E. D. Goldberg, M. Koide, R. A. Schmitt and R. H. Smith, "Rare Earth Distributions in the Marine Environment," Journal of Geophysical Research, Vol. 68, 1963, pp. 4209-4217. doi:10.1029/JZ068i014p04209

[60] D. R. Turner, M. Whitfield and A. G. Dickson, "The Equilibrium Speciation of Dissolved Components in Freshwater and Seawater at $25^{\circ} \mathrm{C}$ and 1 atm Pressure," Geochimica et Cosmochimica Acta, Vol. 45, No. 6, 1981, pp. 855-881. doi:10.1016/0016-7037(81)90115-0

[61] R. C. Morris, "Supergene Alteration of Banded IronFormation," In: A. F. Trendall and R. C. Morris, Eds., 
Iron-Formation: Facts and Problems, Elsevier, Amsterdam, 1983, pp. 513-534.

[62] J. L. Graf, "Rare Earth Elements, Iron Formations and Seawater," Geochimica et Cosmochimica Acta, Vol. 42, No. 12, 1978, pp. 1845-1850. doi:10.1016/0016-7037(78)90239-9

[63] R. F. Dymek and C. Klein, "Chemistry, Petrology and Origin of Banded Iron-Formation Lithologies from the 3800 Ma Isua Supracrustal Belt," West Greenland: Precambrian Research, Vol. 39, No. 4, 1988, pp. 247-302. doi:10.1016/0301-9268(88)90022-8

[64] C. Klein and N. J. Beukes, "Time Distribution, Stratigraphy, and Sedimentologic Setting, and Geochemistry of Precambrian Iron-Formation," In: J. W. Schopf and C. Klein, Eds., The Proterozoic Biosphere: A multidisciplinary study, Cambridge University Press, New York, 1992, pp. 139-146.

[65] F. O. Raposo, E. A. Ladeira, "Petrologia de Formações Ferríferas e Itabiritos do Quadrilátero Ferrífero, Minas Gerais, Brasil," 40th Congresso Brasileiro de Geologia, Sociedade Brasileira de Geologia, Núcleo de Minas Gerais, Belo Horizonte, 1998, p. 158.

[66] B. J. Fryer, "Rare Earth Elements in Iron-Formation," In: A. F. Trendall and R. C. Morris, Eds., Iron-Formations: Facts and Problems, Elsevier, Amsterdam, 1983, pp. 345-358. doi:10.1016/S0166-2635(08)70048-3

[67] A. Michard, F. Albarede, G. Michard, J. F. Minster and J. L. Charlou, "Rare-Earth Elements and Uranium in HighTemperature Solutions from East Pacific Rise hydrothermal Vent Field," Nature, Vol. 303, 1983, pp. 795-797. doi:10.1038/303795a0

[68] A. Danielson, P. Moller and P. Dulski, "The Europium Anomalies in Banded Iron Formations and the Thermal History of the Oceanic-Crust," Chemical Geology, Vol. 97, No. 1-2, 1992, pp. 89-100. doi:10.1016/0009-2541(92)90137-T

[69] C. Alibert and M. T. McCulloch, "Rare Earth Element and Neodymium Isotopic Compositions of Banded Iron Formations and Associated Shales from Hamersley, Western Australia," Geochimica et Cosmochimica Acta, Vol. 57, No. 1, 1993, pp. 187-204. doi:10.1016/0016-7037(93)90478-F

[70] J. F. Slack, T. Grenne, A. Bekker, O. J. Rouxel and P. A. Lindberg, "Suboxic Deep Seawater in the Late Paleoproterozoic: Evidence from Hematitic Chert and Iron Formation Related to Seafloor-Hydrothermal Sulfide Deposits, Central Arizona, USA," Earth and Planetary Science Letters, Vol. 255, No. 1-2, 2007, pp. 243-256. doi:10.1016/j.epsl.2006.12.018

[71] G. Klinkhammer, H. Elderfield and A. Hudson, "RareEarth Elements in Seawater Near Hydrothermal Vents," Nature, Vol. 305, No. 5931, 1983, pp. 185-188. doi: $10.1038 / 305185 \mathrm{a} 0$

[72] J. L. Evans, "The Geology and Geochemistry of the Dyke Lake Area (parts of 23J/8, 9), Labrador," Mineral Development Division, Newfoundland Department of Mines and Energy, 1978, p. 39.

[73] K. Laajoki, "Rare-Earth Elements in Precambrian Iron Formations in Vaydankyla, South Puolanka Area, Fin- land," Bulletin of the Geological Society of Finland, Vol. 47, No. 1-2, 1975, pp. 93-107.

[74] B. J. Fryer "Rare Earth Evidence in Iron Formations for Changing Precambrian Oxidation States," Geochimica et Cosmochimica Acta, Vol. 41, No. 3, 1977, pp. 361-367. doi:10.1016/0016-7037(77)90263-0

[75] B. J. Fryer, "Trace Element Geochemistry of the Sokoman Iron Formation," Canadian Journal of Earth Sciences, Vol. 14, No. 7, 1977, pp. 1598-1610. doi:10.1139/e 77-136

[76] T. J. Barrett, P. W. Fralick and I. Jarvis, "Rare-Earth Element Geochemistry of Some Archean Iron Formations North of Lake Superior, Ontario," Canadian Journal of Earth Sciences, Vol. 25, No. 4, 1988, pp. 570-580. doi:10.1139/e88-055

[77] H. J. W. De Baar, M. P. Bacon and P. G. Brewer, "Rare Earth Distributions with Positive Ce Anomaly in the Western North Atlantic Ocean," Nature, Vol. 301, No. 5898, 1983, pp. 324-327. doi:10.1038/301324a0

[78] C. R. German and H. Elderfield, "Application of the CeAnomaly as a Paleoredox Indicator: The Ground Rules," Paleoceanography, Vol. 5, No. 5, 1990, pp. 823-833. doi:10.1029/PA005i005p00823

[79] R. Byrne and E. Sholkovitz, "Marine Chemistry and Geochemistry of the Lanthanides," In: K. A. Gschneider Jr. and L. Eyring, Eds., Handbook on the Physics and Chemistry of the Rare Earths, Elsevier, Amsterdam, 1996, pp. 497-593.

[80] J. W. Moffett, "Microbially Mediated Cerium Oxidation in Seawater," Nature, Vol. 345, No. 6274, 1990, pp. 421423. doi:10.1038/345421a0

[81] D. Koeppenkastrop and E. H. DeCarlo, "Sorption of Rare Earth Elements from Seawater onto Synthetic Mineral Particles-An Experimental Approach," Chemical Geology, Vol. 95, No. 3-4, 1992, pp. 251-263. doi:10.1016/0009-2541(92)90015-W

[82] H. J. W. De Baar, M. P. Bacon, P. G. Brewer and W. Brulank, "Rare Earth Elements in the Pacific and Atlantic Oceans," Geochimica Cosmochimica Acta, Vol. 49, No. 9, 1985, pp. 1943-1959. doi:10.1016/0016-7037(85)90089-4

[83] H. J. W. De Baar, C. R. German, H. Elderfield and P. Van Gaans, "Rare Earth Element Distributions in Anoxic Waters of the Cariaco Trench," Geochimica et Cosmochimica Acta, Vol. 52, No. 5, 1988, pp. 1203-1219. doi:10.1016/0016-7037(88)90275-X

[84] R. Germanc and H. Elderfield, "Rare Earth Elements in Saanich Inlet, British Columbia, a Seasonally Anoxic Basin," Geochimica Cosmochimica Acta, Vol. 53, No. 10, 1989, pp. 2561-2571. doi:10.1016/0016-7037(89)90128-2

[85] J. J. Braun, M. Pagel, J. P. Muller, P. Bilong, A. Michard and B. Guillet, "Cerium Anomalies in Lateritic Profiles," Geochimica et Cosmochimica Acta, Vol. 54, 1990, pp. 781-789.

[86] J. F. Slack, T. Grenne and A. Bekker, "Seafloor-Hydrothermal Si-Fe-Mn Exhalites in the Pecos Greenstone Belt, New Mexico, and the Redox State of Ca. 1720 Ma Deep Seawater," Geosphere, Vol. 5, No. 3, 2009, pp. 302-314. doi:10.1130/GES00220.1 
[87] S. J. Goldstein and S. B. Jacobsen, "Nd and Sr Isotopic Systematics of River Water Suspended Material: Implications for Crustal Evolution," Earth and Planetary Science Letters, Vol. 87, No. 3, 1988, pp. 249-265. doi:10.1016/0012-821X(88)90013-1

[88] S. J. Goldstein and S. B. Jacobsen, "REE in the Great Whale River Estuary, NW Quebec," Earth and Planetary Science Letters, Vol. 88, No. 1-2, 1988, pp. 241-252. doi:10.1016/0012-821X(88)90081-7
[89] A. Michard and F. Albarède, "The REE Content of Some Hydrothermal Fluids," Chemical Geology, Vol. 55, No. 1-2, 1986, pp. 51-60. doi:10.1016/0009-2541(86)90127-0

[90] J. L. Graf, "Rare Earth Elements as Hydrothermal Tracers during the Formation of Massive Sulfide Deposits in Volcanic Rocks," Economic Geology, Vol. 72, No. 4, 1977, pp. 527-548. doi:10.2113/gsecongeo.72.4.527 